\title{
Strategies to Mitigate Enteric Methane Emissions by Ruminants - A Way to Approach the $2.0^{\circ} \mathrm{C}$ Target
}

Claudia Arndt ${ }^{\mathrm{a}^{*}}$, Alexander N. Hristov ${ }^{\mathrm{b}}$, William J. Price ${ }^{\mathrm{c}}$, Shelby C. McClelland ${ }^{\mathrm{d}}$, Amalia M. Pelaez ${ }^{\mathrm{e}}$, Sergio F. Cueva ${ }^{\mathrm{b}}$, Joonpyo Oh${ }^{\mathrm{b}}$, André Bannink ${ }^{\mathrm{e}}$, Ali R. Bayat ${ }^{\mathrm{f}}$, Les A. Crompton ${ }^{\mathrm{g}}$, Jan Dijkstra ${ }^{\mathrm{e}}$, Maguy A. Eugène ${ }^{\mathrm{h}}$, Ermias Kebreab ${ }^{\mathrm{i}}$, Michael Kreuzer ${ }^{\mathrm{j}}$, Mark McGee $^{\mathrm{k}}$, Cécile Martin ${ }^{\mathrm{h}}$, Charles J. Newbold ${ }^{\mathrm{l}}$, Christopher K. Reynolds ${ }^{\mathrm{g}}$, Angela Schwarm $^{\mathrm{m}}$, Kevin J. Shingfield ${ }^{\mathrm{*} * *}$, Jolien B. Veneman ${ }^{\mathrm{n}}$, David R. Yáñez-Ruiz ${ }^{\circ}$, and Zhongtang $\mathrm{Yu}^{\mathrm{p}}$.

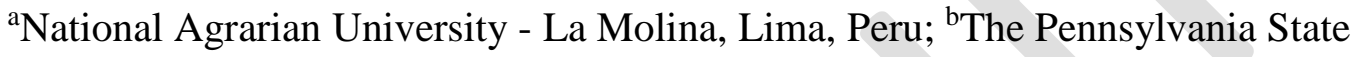
University, University Park, USA; ' University of Idaho, Moscow, USA; ${ }^{\mathrm{d} C o l o r a d o}$ State University, Fort Collins, USA; ${ }^{\mathrm{e}}$ Wageningen University and Research, Wageningen, The

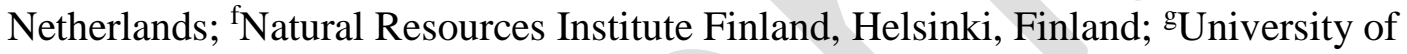
Reading, Earley Gate, Reading, UK; ' INRAE, UCA-VAS, UMRH Centre ARA, SaintGenès-Champanelle, France; ${ }^{\mathrm{i}}$ University of California, Davis, USA; ${ }^{\mathrm{E} E T H}$ Zurich, Zürich,

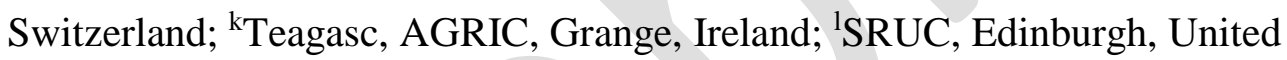
Kingdom; ${ }^{\mathrm{m}}$ Norwegian University of Life Sciences, Aas, Norway; ${ }^{\mathrm{n}}$ De Heus Animal

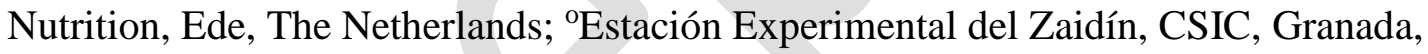
Spain; ${ }^{\mathrm{P} T h e}$ Ohio State University, Columbus, USA.

*Correspondence:

Claudia Arndt

arndt.claudia.ca@gmail.com

**The author is deceased. 


\begin{abstract}
Ruminant livestock enteric fermentation contributes approximately one-third of the global anthropogenic methane $\left(\mathrm{CH}_{4}\right)$ emissions and is projected to increase significantly to meet the increasing demand for animal-sourced protein. Methane, a short-lived greenhouse gas, needs to be reduced -24 to $-47 \%$ by 2050 relative to 2010 to meet the $2.0^{\circ} \mathrm{C}$ target. This study describes the results of a comprehensive meta-analysis to determine effective mitigation strategies. The database included findings from 425 peerreviewed studies (1963 to 2018). Mitigation strategies were classified into three main categories [animal and feed management, diet formulation, and rumen manipulation (additives and methods used to modify the rumen)] and up to five subcategories (98 total mitigation strategy combinations). A random-effects meta-analysis weighted by inverse variance was carried out (Comprehensive Meta-Analysis, V3.3.070). Five feeding strategies, namely $\mathrm{CH}_{4}$ inhibitors, oils and fats, oilseeds, electron sinks, and tanniferous forages, decreased absolute $\mathrm{CH}_{4}$ emissions by on average $-21 \%$ (range -12 to $-35 \%$ ) and $\mathrm{CH}_{4}$ emissions per unit of product $\left(\mathrm{CH}_{4} \mathrm{I}\right.$; meat or milk) by on average $-17 \%$ (range -12 to $-32 \%$ ) without negatively affecting animal production (weight gain or milk yield). Furthermore, three strategies, namely decreasing dietary forage-to-concentrate ratio, increasing feeding level, and decreasing grass maturity, decreased $\mathrm{CH}_{4} \mathrm{I}$ by on average $12 \%$ (range -9 to $-17 \%$ ) and increased animal production by on average $45 \%$ (range 9 to $162 \%)$. The latter strategies are central to meeting the increasing demand for animalsourced food. All strategies, but $\mathrm{CH}_{4}$ inhibitors, can be implemented now and offer immediate approaches for combating global warming.
\end{abstract}

\title{
SIGNIFICANCE STATEMENT
}

Ruminant enteric fermentation is a major contributor to global anthropogenic methane emissions. The demand for animal-sourced products and associated methane emissions are projected to increase, which could prohibit reaching the $2.0^{\circ} \mathrm{C}$ target. This metaanalysis was undertaken to identify effective mitigation strategies to resolve this issue. We determined five strategies (the supplementation of methane inhibitors, oils and fats, oilseeds, electron sinks, and tanniferous forages) that decrease absolute and productbased methane emissions without negatively affecting animal productivity, and three strategies (decreasing dietary forage-to-concentrate ratio, increasing feeding level, and decreasing grass maturity) that decrease product-based methane emissions and increase animal productivity. All strategies, except methane inhibitors, can be adopted now and offer an immediate approach to combat global warming. 


\section{INTRODUCTION}

The goal of the Paris Agreement, to limit global warming to $2.0^{\circ} \mathrm{C}$ above pre-industrial levels, is unlikely to be achieved if food systems continue operating on a business-asusual scenario ${ }^{1}$. Thus, it is of utmost importance to determine and implement strategies that mitigate food-related greenhouse gas (GHG) emissions. Among the food-related GHG emissions, methane $\left(\mathrm{CH}_{4}\right)$ emissions from enteric fermentation by ruminant livestock contribute $30 \%$ of the global anthropogenic $\mathrm{CH}_{4}$ emissions ${ }^{2}$. $\mathrm{As}^{\mathrm{CH}_{4}}$ is a powerful but short-lived GHG, decreasing global $\mathrm{CH}_{4}$ emissions is especially important for limiting global warming in the short-term. This urgency has been underlined by the European Commission, which recently published the EU Methane Strategy ${ }^{3}$ that is essential to meet the EU's nationally determined contributions under the Paris Agreement and its 2050 climate neutrality goal.

In addition to the Paris Agreement, the international community also agreed to 17 Sustainable Development Goals (SDGs) to achieve sustainable development by $2030^{4}$. These include SDG 1 - no poverty, SDG 2 - no hunger, and SDG 13 - climate action. Consequently, measures to address SDG 13 (climate action) cannot countervail other SDGs, in particular SDG 2 (zero hunger). This is explicitly highlighted in article 2.1 (b) of the Paris Agreement "Increasing the ability to adapt to the adverse impacts of climate change and foster climate resilience and low greenhouse gas emissions development, in a manner that does not threaten food production" 5 .

Given all this, effective mitigation strategies that comply with both SDG 13 (climate action) and SDG 2 (zero hunger) are urgently needed. Accordingly, the challenge facing food systems is the need to reduce $\mathrm{CH}_{4}$ emissions from animal production by -24 to $-47 \%$ by 2050 relative to $2010^{6}$, while simultaneously increasing the production of animalsourced food to meet the projected 68\% increase in demand between 2010 and $2050^{7}$. Reaching these apparently conflicting twin goals will require effective enteric $\mathrm{CH}_{4}$ mitigation strategies that, at a minimum, do not compromise animal productivity or have other unacceptable tradeoffs ${ }^{8}$ and, ideally, increase animal-sourced food production. Strategies that increase animal production and reduce product-based $\mathrm{CH}_{4}$ emissions (i.e., emission intensity variables $\mathrm{CH}_{4} \mathrm{I}_{\mathrm{G}}$ and $\mathrm{CH}_{4} \mathrm{I}_{\mathrm{M}}$, emission per unit of weight gain or milk produced, respectively) are especially paramount in low and middle-income countries where productivity and production per animal are $\operatorname{low}^{9,10}$. Advocates of reducing the global ruminant population as a means to achieve climate change mitigation goals have acknowledged that this approach is particularly inappropriate for low-income countries ${ }^{11}$. Therefore ruminants are of major importance to achieving SDG 2 (zero hunger), as they provide food for human consumption from marginal lands and in subsistence agriculture situations. 
Several reviews have determined that animal and feed management, diet formulation, and rumen manipulation strategies could significantly decrease enteric $\mathrm{CH}_{4}$ emissions ${ }^{8,12,13}$. However, thus far studies either only investigated the quantitative effects of a single mitigation strategy or only compared $\mathrm{CH}_{4}$ yield $\left(\mathrm{CH}_{4} \mathrm{Y} ; \mathrm{CH}_{4}\right.$ per unit of feed intake) between multiple mitigation strategies. Nonetheless, $\mathrm{CH}_{4} \mathrm{Y}$ is only one measure and other important $\mathrm{CH}_{4}$ emission and animal performance metrics must be considered to determine the effectiveness and feasibility of mitigation strategies. Important $\mathrm{CH}_{4}$ emission metrics include daily $\mathrm{CH}_{4}$ emissions, $\mathrm{CH}_{4} \mathrm{Y}, \mathrm{CH}_{4}$-energy conversion factor [ $\mathrm{Y}_{\mathrm{m}}$; $\mathrm{CH}_{4}$ energy as a proportion of gross energy intake; a component of the Tier 2 calculation for national GHG inventories recommended by the Intergovernmental Panel on Climate Change $\left.{ }^{14}\right], \mathrm{CH}_{4} \mathrm{I}_{\mathrm{G}}$, and $\mathrm{CH}_{4} \mathrm{I}_{\mathrm{M}}$. Important animal performance metrics include feed intake, nutrient digestibility, and animal production.

The objective of this study was to conduct a comprehensive meta-analysis of enteric $\mathrm{CH}_{4}$ mitigation strategies published in peer-reviewed journals by examining their quantitative effects on the aforementioned $\mathrm{CH}_{4}$ emission and animal performance metrics. There is an urgent requirement for strategies that can effectively mitigate both absolute and productbased $\mathrm{CH}_{4}$ emissions without negatively affecting animal productivity or that can effectively mitigate product-based $\mathrm{CH}_{4}$ emissions while increasing animal-sourced food production. Our approach of identifying effective 'dual-action' strategies ensures that both the 'climate action' objective of SDG 13 and the 'zero hunger' objective of SDG 2 are targeted simultaneously. 


\section{RESULTS AND DISCUSSION}

The meta-analysis included 98 mitigation strategies reported in 425 peer-review journal publications (Supplementary Table 1). Mitigation strategies were classified into three main categories: animal and feed management, diet formulation, or rumen manipulation strategies. Of the strategies included, 63 did not significantly (adjusted $P \geq 0.05$ ) decrease daily $\mathrm{CH}_{4}$ emissions; the remaining 35 strategies decreased daily $\mathrm{CH}_{4}$ emissions and $\mathrm{CH}_{4} \mathrm{Y}$ by on average $-18 \%$ (ranging from -5 to $-43 \%$ ) and $-14 \%$ (ranging from -4 to $37 \%$ ), respectively. These strategies were classified as 'effective' in decreasing absolute and product-based $\mathrm{CH}_{4}$ emissions, if they significantly (adjusted $P<0.05$ ) decreased daily $\mathrm{CH}_{4}$ emissions, $\mathrm{CH}_{4} \mathrm{Y}$, and $\mathrm{CH}_{4} \mathrm{I}_{\mathrm{G}}$ or $\mathrm{CH}_{4} \mathrm{I}_{\mathrm{M}}$ without decreasing animal production (weight gain of growing animals or milk yield of dairy animals) when production data were present. Strategies were also classified as 'effective' in decreasing product-based $\mathrm{CH}_{4}$ emissions if they significantly decreased $\mathrm{CH}_{4} \mathrm{Y}$ and $\mathrm{CH}_{4} \mathrm{I}_{\mathrm{G}}$ or $\mathrm{CH}_{4} \mathrm{I}_{\mathrm{M}}$ while significantly increasing animal production. A summary of the studied mitigation strategies is presented in Fig. 1 and the full list of the studied mitigation strategies is presented in Supplementary Tables 2.

Effective mitigation strategies in the order of efficacy and their effect on $\mathrm{CH}_{4}$ and animal performance metrics as well as their relevance for confinement or grazing systems are presented in Fig. 2. As $\mathrm{CH}_{4} \mathrm{Y}$ was highly correlated with $\mathrm{Y}_{\mathrm{m}}$ (adjusted $\mathrm{R}^{2}=0.83$; Supplementary Fig. 1) and more data were available for $\mathrm{CH}_{4} \mathrm{Y}$ than for $\mathrm{Y}_{\mathrm{m}}$ (Supplementary Fig. 2), only results for $\mathrm{CH}_{4} \mathrm{Y}$ are presented and discussed here. All other strategies that were not classified as effective but had a significant effect on $\mathrm{CH}_{4}, \mathrm{CH}_{4} \mathrm{Y}$, $\mathrm{Y}_{\mathrm{m}}, \mathrm{CH}_{4} \mathrm{I}_{\mathrm{G}}$ or $\mathrm{CH}_{4} \mathrm{I}_{\mathrm{M}}$ are presented in Supplementary Fig. 3 to 5. The $\mathrm{CH}_{4}$ inhibitor bromochloromethane was not classified as effective, despite fulfilling the selection criteria for an effective mitigation strategy, because it is an ozone-depleting compound that is harmful to aquatic organisms and a confirmed carcinogen ${ }^{15}$. Furthermore, several mitigation strategies were excluded from the present evaluation or classified as ineffective because of insufficient publications and warrant further research. These include breeding low- $\mathrm{CH}_{4}$ emitting animals and improving animal health. Modeling studies have shown that strategies that improve animal health can significantly increase animal productivity and reduce emission intensity ${ }^{16}$. In the subsequent text, the effects of mitigation strategies on $\mathrm{CH}_{4}$ emissions and animal performance metrics are reported in parenthesis as mean, $95 \%$ confidence interval $(\mathrm{CI})$, and number of treatment comparisons (n). Reported differences were significant (adjusted $P<0.05$ ) unless indicated otherwise. 


\section{Strategies that decrease absolute and product-based $\mathrm{CH}_{4}$ emissions}

Rumen manipulation by feeding $\mathrm{CH}_{4}$ inhibitors effectively decreased daily $\mathrm{CH}_{4}$ emissions (mean $=-35 \%, 95 \% \mathrm{CI}=-30$ to $-40 \%, \mathrm{n}=23$, throughout the paper). Within this category, 3-nitrooxypropanol (3-NOP) is most effective acting on methyl-coenzyme $\mathrm{M}$ reductase, a key enzyme of the methanogenesis pathway of archaea ${ }^{17}$. Its supplementation decreased daily $\mathrm{CH}_{4}$ emissions (-39\%, -29 to $\left.-47 \%, 11\right), \mathrm{CH}_{4} \mathrm{Y}(-37 \%$, 26 to $-46 \%, 12)$, and $\mathrm{CH}_{4} \mathrm{I}_{\mathrm{M}}(-31 \%,-21$ to $-40 \%, 2)$ without affecting feed intake or milk yield. Insufficient data were available to evaluate its effect on weight gain or fiber digestibility in this analysis. However, in recent studies, 3-NOP did not show adverse effects on weight gain of growing beef cattle ${ }^{18}$ or fiber digestibility in early-lactation dairy cows ${ }^{19}$ and decreased daily $\mathrm{CH}_{4}$ emissions throughout a 15 -week experiment ${ }^{20}$. A recent meta-analysis showed that 3-NOP decreases daily $\mathrm{CH}_{4}$ emissions in a doseresponse manner, that its mitigation effect is greater for dairy than beef cattle, and that its effectiveness decreases with increasing dietary fiber content ${ }^{21}$. In its current form, 3-NOP can only be used in confinement systems, because it is more effective when fed continuously within the animals' $\operatorname{diet}^{20,22}$, but ongoing research is developing mechanisms for its application under grazing conditions ${ }^{23}$. Supplementation of 3-NOP increased milk fat content in dairy cattle ${ }^{19}$ and feed efficiency in feedlot cattle ${ }^{24}$, which may help offset its cost and stimulate adoption. A limitation of 3-NOP is that its use as a feed additive requires regulatory approval by various countries. Another $\mathrm{CH}_{4}$ inhibitor strategy is supplementation with seaweed (e.g. Asparagopsis taxiformis), which can decrease daily $\mathrm{CH}_{4}$ emissions by up to $80 \%{ }^{25}$. However, more research is warranted on dietary inclusion levels, effects on animal feed intake and production ${ }^{26}$, the implications and safety of feeding bromoform ${ }^{27}$, its main active compound ${ }^{28}$, the extremely high iodine content of Asparagopsis species (which limits how much can be fed in many countries), as well as the environmental effects of cultivating seaweed ${ }^{29}$ before it can be recommended as a mitigation strategy.

Dietary inclusion of oil and fat decreased daily $\mathrm{CH}_{4}$ emissions $(-20 \%,-15$ to $-24 \%, 63)$ and $\mathrm{CH}_{4} \mathrm{Y}(-15 \%,-11$ to $18 \%, 52)$. Weight gain in growing animals or milk production in dairy animals was unaffected despite decreasing feed intake $(-6 \%,-3$ to $-8 \%, 58)$ and fiber digestibility $(-4 \%,-2$ to $-7 \%, 37)$. This resulted in decreased $\mathrm{CH}_{4} \mathrm{I}_{\mathrm{G}}(-22 \%,-8$ to $35 \%, 6)$ and $\mathrm{CH}_{4} \mathrm{I}_{\mathrm{M}}(-12 \%,-6$ to $-18 \%, 24)$; however, possible effects on manure $\mathrm{CH}_{4}$ emissions due to decreased fiber digestibility need to be evaluated ${ }^{14}$. Of the subcategories included here, only dietary inclusion of predominantly vegetable oils effectively decreased daily $\mathrm{CH}_{4}$ emissions. This effect can be attributed to increased supply of nonfermentable highly digestible energy, a decreased feed intake and fiber digestibility as well as inhibition of methanogenesis by unsaturated (or medium-chain saturated) fatty 
acids, which are usually abundant in vegetable oils. Other meta-analyses also found that oil inclusion decreased $\mathrm{CH}_{4} \mathrm{Y}$ (between -9 to $-14 \%$ ), feed intake (-6\%) and increased milk yield $(+4 \%)^{13,30}$. Oil inclusion reportedly decreases daily $\mathrm{CH}_{4}$ emissions in a doseresponse manner ${ }^{30}$ and over the long-term ${ }^{31,32}$. The amount of oil that can be included in ruminant diets, however, is limited and inclusion level should not be at the expense of healthy rumen fermentation that may negatively impact animal health and productivity. Maximum oil inclusion levels in ruminant diets depend on the animals' physiological stage, lipid and other nutrient composition of the basal diet, and fatty acid profile of the supplemental oil ${ }^{33}$. Vegetable oils that effectively decreased daily $\mathrm{CH}_{4}$ emissions were: (1) coconut oil $(-28 \%,-20$ to $-35 \%, 16)$, (2) canola oil $(-22 \%,-12$ to $-32 \%, 4)$, (3) linseed oil $(-22 \%,-14$ to $-29 \%, 14)$, and (4) sunflower oil $(-17 \%,-9$ to $-24 \%, 5)$. The costeffectiveness of feeding oils to decrease daily $\mathrm{CH}_{4}$ emissions likely varies by region and country, because oil and meat and milk prices vary considerably therein. Studies in China $^{34}$, France ${ }^{35}$, or the Netherlands ${ }^{36}$ found that dietary inclusion of oils, for the purpose of mitigating enteric $\mathrm{CH}_{4}$ emissions, was not cost-effective, but trade-offs by concomitant improvements in the fatty acid profile of milk and meat from a humanhealth perspective might help to support the implementation of certain oils and oilseeds.

Dietary inclusion of oilseeds (cracked or crushed) had similar effects on $\mathrm{CH}_{4}$ emissions and animal performance metrics as the inclusion of oils, even though part of the oil in crushed oilseeds is rumen-protected. Oilseeds decreased daily $\mathrm{CH}_{4}$ emissions $(-20 \%,-15$ to $-24 \%, 26), \mathrm{CH}_{4} \mathrm{Y}(-14 \%,-8$ to $-20 \%, 18)$, and $\mathrm{CH}_{4} \mathrm{I}_{\mathrm{M}}(-12 \%,-4$ to $-19 \%, 6)$, tended to decrease feed intake $(-4 \%,-1$ to $-7 \%, 25, P=0.06)$, and decreased fiber digestibility ($8 \%,-6$ to $-11 \%, 13)$. Similar to oils, oilseeds had no effect on milk yield but decreased weight gain in growing animals $(-13 \%,-6$ to $-20 \%, 8)$; thus, dietary oilseed inclusion may only be recommended for lactating dairy animals and not for growing animals. Likewise, the inclusion of oilseeds needs to be limited to not negatively impact rumen fermentation, animal health and production. However, as part of the oil in oilseeds is rumen-protected, dietary inclusion levels can be slightly higher than oils ${ }^{37}$. In addition, similar to oil inclusion possible effects on manure $\mathrm{CH}_{4}$ emissions due to decreased fiber digestibility need to be evaluated. Oilseeds that effectively decreased daily $\mathrm{CH}_{4}$ emissions were: (1) sunflower seeds $(-39 \%,-15$ to $-57 \%, 3)$, (2) cottonseeds $(-19 \%,-13$ to $-23 \%, 7),(3)$ linseeds $(-17 \%,-2$ to $-29 \%, 4)$ and (4) canola seeds $(-13 \%,-10$ to $-16 \%, 8)$.

Rumen manipulation with electron sinks, alternative electron acceptors that can redirect hydrogen from methanogenic archaea towards metabolically beneficial sinks in the rumen ${ }^{38}$, decreased daily $\mathrm{CH}_{4}$ emissions $(-17 \%,-14$ to $-20 \%, 54)$ and $\mathrm{CH}_{4} \mathrm{Y}(-15 \%,-13$ to $-18 \%, 51)$. Despite small decreases in feed intake $(-2 \%,-1$ to $-3 \%, 49)$ small increases in milk yield $(+3 \%,+1$ to $+5 \%, 13)$ were observed, resulting in decreased $\mathrm{CH}_{4} \mathrm{I}_{\mathrm{G}}(-12 \%,-2$ 
to $-20 \%, 3)$ and $\mathrm{CH}_{4} \mathrm{I}_{\mathrm{M}}(-13 \%,-9$ to $-16 \%, 12)$. Of the studied electron sinks (fumaric acid and nitrate), only nitrate was classified as effective. Another meta-analysis found similar effects of nitrate on daily $\mathrm{CH}_{4}$ emissions $(-15 \%)^{39}$. Nitrate has also been shown to decrease daily $\mathrm{CH}_{4}$ emissions and $\mathrm{CH}_{4} \mathrm{Y}$ in a dose-response manner with no loss of effectiveness over and effectively decreased $\mathrm{CH}_{4}$ over the long-term ${ }^{40,41}$. Similar to 3NOP, nitrate was more effective in decreasing daily $\mathrm{CH}_{4}$ emissions and $\mathrm{CH}_{4} \mathrm{Y}$ in dairy than in beef cattle ${ }^{39}$. Although nitrate can be toxic, early research on nitrate supplementation in ruminant diets reported a decrease in feed intake and no toxicity symptoms; however, toxicity can occur if animals are not properly acclimatized ${ }^{42}$. Acclimatization of animals to dietary nitrate is required to avoid methemoglobinemia, but rumen adaptation can be lost within three weeks if nitrate is not continuously fed ${ }^{43}$. Simultaneous sulfate supplementation has been shown to help protect cattle against nitrate toxicity ${ }^{40}$. Nitrate supplementation may increase enteric and possibly manure nitrous oxide emissions ${ }^{44}$. Studies in France ${ }^{35}$ and the Netherlands ${ }^{36}$ found that nitrate supplementation was not cost-effective.

Dietary inclusion of tanniferous forages decreased daily $\mathrm{CH}_{4}$ emissions $(-12 \%,-7$ to $16 \%, 42)$ and $\mathrm{CH}_{4} \mathrm{Y}(-10 \%,-6$ to $-14 \%, 39)$ without affecting feed intake or animal production and consequently decreased $\mathrm{CH}_{4} \mathrm{I}_{\mathrm{M}}(-18 \%,-8$ to $-26 \%, 7)$. However, it also decreased fiber digestibility $(-7 \%,-2$ to $-12 \%, 21)$, which could potentially increase manure $\mathrm{CH}_{4}$ emissions ${ }^{14}$. Sericea lespedeza (Lespedeza cuneata) decreased daily $\mathrm{CH}_{4}$ emissions $(-32 \%,-24$ to $-39 \%, 5)$ without affecting feed intake in goats and it has been effective in decreasing daily $\mathrm{CH}_{4}$ emissions throughout a 12 -week experiment ${ }^{45}$. Other tanniferous forages that may potentially decrease daily $\mathrm{CH}_{4}$ emissions are Leucaena ($8 \%, 0$ to $-16 \%, 12, P=0.10)$ and Lotus (corniculatus and pedunculatus) $(-8 \%,-3$ to $13 \%, 3)$. Although this meta-analysis did not reveal any effect on feed intake, tanniferous forages have been associated with decreased palatability and feed intake ${ }^{46}$. Tannins can bind to dietary protein and thus decrease protein digestion and animal production, especially when dietary protein is limiting. Nevertheless, when dietary protein is excessive or highly degradable, tannins may be beneficial, because they reduce excretion of nitrogen in urine, which decreases ammonia and nitrous oxide emissions from manure $^{47}$. The cost-effectiveness of their supplementation still needs to be evaluated. Among the identified effective strategies to decrease absolute and product-based $\mathrm{CH}_{4}$ emissions, dietary inclusion of tanniferous forages is the only one applicable to both confinement and grazing systems. This is important as $37 \%$ of global enteric $\mathrm{CH}_{4}$ emissions are attributed to grazing systems ${ }^{48}$. 


\section{Strategies that decrease product-based $\mathrm{CH}_{4}$ emissions}

Decreasing dietary forage-to-concentrate ratio decreased $\mathrm{CH}_{4} \mathrm{Y}(-13 \%,-10$ to $-16 \%, 69)$ without increasing daily $\mathrm{CH}_{4}$ emissions despite increasing feed intake $(+9 \%,+5$ to $+14 \%$, $85)$. The associated increase in overall feed intake did not affect fiber digestibility and led to an increase in weight gain $(+21 \%,+13$ to $+29 \%, 32)$ and milk yield $(+17 \%,+10$ to $+24 \%, 26)$. Consequently, $\mathrm{CH}_{4} \mathrm{I}_{\mathrm{G}}(-9 \%,-3$ to $-15 \%, 16)$ and $\mathrm{CH}_{4} \mathrm{I}_{\mathrm{M}}(-9 \%,-4$ to $-14 \%, 19)$ were decreased. The reduction in $\mathrm{CH}_{4} \mathrm{Y}$ was most likely the result of a shift in rumen fermentation patterns and a decrease in rumen $\mathrm{pH}$, which inhibits methanogens ${ }^{38}$. However, the supplementation of grain-based concentrate needs to be limited, because overfeeding can lead to subacute ruminal acidosis. Subacute ruminal acidosis is a nutritional disease that is associated with perturbation of rumen fermentation and decreased fiber digestibility, milk fat content, and animal health mostly found in feedlot and high-yielding dairy cattle ${ }^{49}$. In addition, the promotion of increased use of (foodquality) grain-based concentrate in ruminant diets will likely intensify feed-food competition. In contrast, if concentrate-rich diets are mainly based on food industry byproducts, the feed food-competition may be avoided. The cost-effectiveness of this strategy will depend on forage and concentrate costs as well as associated increases in animal production and the price of animal products (meat and milk).

Increasing feeding level $(+58 \%,+47$ to $+71 \%, 47)$ increased daily $\mathrm{CH}_{4}$ emissions $(+18 \%,+14$ to $+22 \%, 42)$, but decreased $\mathrm{CH}_{4} \mathrm{Y}(-8 \%,-4$ to $-12 \%, 31)$. Fiber digestibility was decreased $(-7 \%,-2$ to $-12 \%, 18)$, likely due to increased rumen passage rates ${ }^{50}$. Increasing feed intake resulted in increased weight gain $(+162 \%,+38$ to $+398 \%, 7)$ and milk yield $(+17 \%,+10$ to $+25 \%, 8)$ and decreased $\mathrm{CH}_{4} \mathrm{I}_{\mathrm{M}}(-17 \%,-9$ to $-23 \%, 5)$. No data were available for $\mathrm{CH}_{4} \mathrm{I}_{\mathrm{G}}$. Similar to our data, a recent study showed that increasing the level of feeding decreased $\mathrm{CH}_{4} \mathrm{Y}$, while increasing daily $\mathrm{CH}_{4}{ }^{51}$. Increasing feed intake to improve animal productivity significantly decreases $\mathrm{CH}_{4} \mathrm{I}_{\mathrm{G}}$ and $\mathrm{CH}_{4} \mathrm{I}_{\mathrm{M}},{ }^{8,52}$ and the overall carbon footprint of animal-sourced food ${ }^{53}$ when diet composition remains unchanged. This strategy directs energy for $\mathrm{CH}_{4}$ towards animal production ${ }^{51}$ but also decreases energy requirements for maintenance relative to milk production and reduces the time to slaughter for growing animals. Increased feeding level also causes differences in digestive efficiency including microbial metabolism, particle passage and digestive kinetics, all of which contribute to the negative relationship between $\mathrm{CH}_{4} \mathrm{Y}$ and increasing feed intake ${ }^{8}$. Potential effects of this practice on manure $\mathrm{CH}_{4}$ emissions, as a result of decreased fiber digestibility, need to be evaluated. The practice is applicable to both confinement and grazing systems, but particularly the latter and especially in certain climatic regions where animals are underfed due to insufficient or low nutritive forage $\mathrm{e}^{54}$. 
Decreasing grass maturity decreased $\mathrm{CH}_{4} \mathrm{Y}(-4 \%,-1$ to $-8 \%, 8)$ but not daily $\mathrm{CH}_{4}$ emissions. It did not affect feed intake but increased milk yield $(+9 \%,+1$ to $+18 \%, 6)$ and thus decreased $\mathrm{CH}_{4} \mathrm{I}_{\mathrm{M}}(-13 \%$, -7 to $-18 \%, 6)$. Furthermore, decreasing grass maturity improved fiber digestibility $(+15 \%,+9$ to $+21 \%, 9)$, which can potentially decrease manure $\mathrm{CH}_{4}$ emissions ${ }^{14}$. Insufficient data were available for growing animals and thus, based on our analysis this mitigation strategy can currently only be recommended for lactating animals. The positive effect of decreasing grass maturity on milk yield is likely attributed to greater digestible energy and protein content. Increased protein content, however, can lead to increased nitrogen intake and excretion ${ }^{55}$. Thus, possible tradeoffs associated with direct and indirect manure nitrous oxide emissions require further evaluation. This strategy is applicable to both confinement and grazing systems. Although decreasing grass maturity increases the overall efficiency of dietary nutrient use for milk production (kg milk per unit of feed intake) and milk production, it was not deemed to be cost-effective in the Netherlands; however, it was more cost-effective than supplementation with nitrate or linseed ${ }^{36}$. 


\section{CONCLUSION}

Effective strategies that reduced daily and product-based $\mathrm{CH}_{4}$ emissions without negatively affecting animal production decreased daily $\mathrm{CH}_{4}$ emissions by on average $21 \%$ (range from -10 to $-35 \%$ ) and product-based emissions by on average $-17 \%$ (range from -12 to $-32 \%$ ). Strategies that reduced product-based $\mathrm{CH}_{4}$ emissions and increased animal production decreased product-based $\mathrm{CH}_{4}$ emissions by on average - $12 \%$ (range from -9 to $-17 \%$ ), and increased animal production by on average $+45 \%$ (range from +9 to $+162 \%$ ). Nevertheless, future studies should continue to explore novel mitigation strategies and possible synergistic effects of combining effective mitigation strategies, e.g. 3-NOP with lipids or lipids with nitrates, to develop innovative strategies that have a large mitigation potential. In addition, possible tradeoffs and pollution swapping with upstream processes, such as GHG emissions associated with feed productions as well as manure GHG emissions that could offset gains in enteric $\mathrm{CH}_{4}$ mitigation need to be investigated. Of the effective strategies that decrease absolute and product-based $\mathrm{CH}_{4}$ emissions, only tanniferous forages are applicable in grazing systems, and it is of utmost importance that more strategies are developed for these systems. Strategies that mitigate enteric $\mathrm{CH}_{4}$ emissions whilst improving animal production are of particular relevance in view of the significant role of ruminants in providing food for human consumption in low-income countries. All identified effective mitigation strategies, except for the supplementation of 3-NOP, could be implemented today. Owing to the short-lived manner of $\mathrm{CH}_{4}$ as a GHG, any such strategy implemented today will significantly reduce the contributions of food systems to global warming by 2030 , and is a way to approach the $2^{\circ} \mathrm{C}$ target. 


\section{Materials and Methods}

Literature Search and Classification of Mitigation Strategies. The database for this meta-analysis was compiled using data obtained by searching the databases of the Commonwealth Agricultural Bureau International (CABI), the EBSCO Discovery Service, and the Web of Science from 1964 to 2018. Publications from 1964 through 2016 were searched using CABI and EBSCO Discovery Service with the search terms 'rumen' AND 'methane' and an additional four searches were completed in the EBSCO Discovery Service using the term 'rumen' in combination with 'methane', 'energy partitioning', 'energy metabolism', or 'energy balance'. Publications from 2017 through 2018 were searched using CABI and Web of Science databases. Seven searches were conducted with the search term 'methane' in combination with 'beef', 'cattle', 'dairy', 'goat', 'sheep', 'rumen', or 'ruminant' and three searches with the search term 'rumen' in combination with 'energy balance', 'energy metabolism', or 'energy partitioning'. Publications listed in an independently developed database supported by the AnimalChange project, MitiGate ${ }^{13}$, were merged with the database created in the current analysis. The abstracts of the publications found in the search were reviewed and, based on abstract content, publications were selected for further consideration if they included in vivo measurement of enteric $\mathrm{CH}_{4}$ emissions, a clearly defined treatment and control, and multiple replications (i.e., at least four or more animals in continuous design experiments, crossover design experiments, etc.). Publications were excluded if they were not from peer-reviewed literature or if they were not in English, French, German, or Portuguese. Furthermore, publications were excluded if they were based on inappropriate study design (i.e., experimental period $\leq 10$ days) or measurement technique (e.g. the 'sniffer technique' that is based on the $\mathrm{CH}_{4}$-to-carbon dioxide ratio of exhaled breath ${ }^{56,57}$ ). The completed database consisted of 650 publications. From these, only publications that had a treatment that could be assigned to one of three main mitigation categories, as described below, and reported statistical variance for at least one of the $\mathrm{CH}_{4}$ emissions emission metrics (e.g. LSD, RSD, or SE of the mean) were included in the final analysis. WebPlotDigitizer (https://automeris.io/WebPlotDigitizer/; accessed 30 October 2019) was used to determine absolute values for a total of nine metrics in seven publications where data were reported as figures.

Data were classified into three main mitigation categories: (1) animal and feed management, (2) diet formulation, and (3) rumen manipulation, each of which was then further classified into up to five subcategories (Supplementary Table 2). Only mitigation strategies, for which at least two publications were available for at least one $\mathrm{CH}_{4}$ emission metric and two of the remaining $\mathrm{CH}_{4}$ emission or animal metrics, were analyzed within a main category. Treatment effects were assessed relative to their respective control values for all responses, therefore, closely related variables and variables with 
different units were included in the analysis. For example, $\mathrm{CH}_{4} \mathrm{I}_{\mathrm{M}}$ included daily $\mathrm{CH}_{4}$ emissions per liter of milk and milk corrected for fixed energy, fat and protein, or milk solids (all milk non-water components combined) content as well as milk solids yield. Similarly, for $\mathrm{CH}_{4} \mathrm{I}_{\mathrm{G}}$, both weight gain and carcass gain were used. Metrics for feed intake included intakes of dry matter, gross energy, organic matter, and intake expressed per unit of body weight or metabolic body weight. Digestibility (of fiber) metrics included only apparent digestibility of neutral detergent fiber. Where multiple treatments of a common treatment type were present within an experiment, those treatment means were averaged, and their respective errors pooled, such that each experiment produced a single "Treatment" and "Control" pair of response means and SDs.

The final meta-analysis included data from 425 peer-reviewed publications, of which $66 \%$ were with cattle, $31 \%$ with small ruminants (sheep and goats) and $3 \%$ with other ruminant species (buffalo, deer, and yak). The complete list of references used in the current analysis is given in Supplementary Table 1. The majority of publications reported daily $\mathrm{CH}_{4}$ emissions (92\%), feed intake (84\%), and $\mathrm{CH}_{4} \mathrm{Y}(71 \%)$, whereas less than half of the publications reported weight gain for all animal types (growing, lactating, and other adult animals) (49\%), $\mathrm{Y}_{\mathrm{m}}(48 \%)$, fiber digestibility (41\%), milk yield (29\%), $\mathrm{CH}_{4} \mathrm{I}_{\mathrm{M}}$ (21\%), or $\mathrm{CH}_{4} \mathrm{I}_{\mathrm{G}}(7 \%)$ (Supplemental Fig. 2). The final analysis only included weight gain data for growing animals (106 publications), which led to the exclusion of the weight gain data of half of the publications (104) that reported weight gain data for lactating and other adult animals.

Statistical Analysis. A mixed model meta-analysis weighted by inverse variance was carried out considering treatment mean comparisons within publication as a random effect. Analyses were run across all ruminant species (cattle, buffalo, deer, goat, sheep, and yak) and included main mitigation strategies and their respective subcategories as potential moderator fixed effects. Analyses were conducted separately for each of the nine response variables (daily $\mathrm{CH}_{4}, \mathrm{CH}_{4} \mathrm{Y}, \mathrm{Y}_{\mathrm{m}}, \mathrm{CH}_{4} \mathrm{I}_{\mathrm{G}}, \mathrm{CH}_{4} \mathrm{I}_{\mathrm{M}}$, feed intake, weight gain for growing animals, milk yield, and fiber digestibility) using a log ratio of means, namely $\log$ (Treatment/Control), in order to standardize treatment effects across multiple measures, species, and outcomes, as well as to allow the expression of treatment differences as relative percentages ${ }^{58,59}$. Weight gain for growing animals when consuming tanniferous plants, however, was assessed based on a standardized relative difference, [(Treatment-Control)/SE $\left.\mathrm{SE}_{\text {Diff }}\right]$, due to the presence of negative growth rate responses in two treatment mean comparisons ${ }^{59}$. Computations were carried out using Comprehensive Meta-Analysis (V. 3.3.070; Biostat, Englewood, NJ). All analyses were adjusted for multiple comparisons using a step-down Bonferroni procedure to reduce the risk of Type I error $^{60}$ (SAS, V. 9.4; SAS Inst. Inc, Cary, NC). The effect of a mitigation strategy was considered to be significant for adjusted $P<0.05$ and $0.05 \leq$ adjusted $P \leq 0.10$ was considered as a trend. 


\section{ACKNOWLEDGMENTS}

The authors want to thank the GLOBAL NETWORK project for generating part of the database. The GLOBAL NETWORK project (https://globalresearchalliance.org/research/livestock/collaborative-activities/globalresearch-project/; accessed 20 June, 2020) was a multi-national initiative funded by the Joint Programming Initiative on Agriculture, Food Security and Climate Change and was coordinated by the Feed and Nutrition Network (https://globalresearchalliance.org/research/livestock/networks/feed-nutrition-network/; accessed 20 June, 2020) within the Livestock Research Group of the Global Research Alliance on Agricultural GHG (https://globalresearchalliance.org; accessed 20 June, 2020).

The authors want to thank MitiGate, which was part of the AnimalChange project funded by the EU under Grant Agreement FP7-266018 for sharing their database with us (http://mitigate.ibers.aber.ac.uk/, accessed July 1, 2017). Part of C. Arndt's, A. N. Hristov's, and S. C. McClelland's time in the early stages of this project was funded by the Kravis Scientific Research Fund (New York, NY) and a gift from Sue and Steve Mandel to Environmental Defense Fund. Another part of C. Arndt's work on this project was supported by the FONDECYT contract ( $N^{\circ}$ 016-2019-FONDECYT-BM-INC.INV) and of A. Hristov's work by the USDA (Washington, DC) National Institute of Food and Agriculture Federal Appropriations under Project PEN 04539 and Accession Number 1000803. E. Kebreab was supported by the Sesnon Endowed Chair Fund of the University of California, Davis. 


\section{REFERENCES}

1. M. A. Clark, et al., Global food system emissions could preclude achieving the $1.5^{\circ}$ and $2^{\circ} \mathrm{C}$ climate change targets. Science 370, 705-708 (2020).

2. R. Jackson, et al., Increasing anthropogenic methane emissions arise equally from agricultural and fossil fuel sources. Environ. Res. Lett. 15, 071002 (2020).

3. European Commission, EU strategy to reduce methane emissions, Brussels, 14 October 2020, $\operatorname{COM}(2020) 663$ final. Available at https://ec.europa.eu/energy/sites/ener/files/eu_methane_strategy.pdf

4. UN General Assembly, Transforming our world: the 2030 Agenda for Sustainable Development, 21 October 2015, A/RES/70/1. Available at https://www.refworld.org/docid/57b6e3e44.html

5. United Nations / Framework Convention on Climate Change (2015) Adoption of the Paris Agreement, 21st Conference of the Parties, Paris: United Nations.

6. IPCC. In Global Warming of $1.5^{\circ} \mathrm{C}$ (eds. V. Masson-Delmotte et al.) (IPCC, Geneva, 2018).

7. T. Searchinger, R. Waite, C. Hanson, J. Ranganathan, Creating a Sustainable Food Future (World Resources Institute, Washington D.C., 2019).

8. A. N. Hristov et al., Special topics - Mitigation of methane and nitrous oxide emissions from animal operations: I. A review of enteric methane mitigation options. J. Anim. Sci. 91, 5045-5069 (2013).

9. M. Balehegn et al., Improving adoption of technologies and interventions for increasing supply of quality livestock feed in low- and middle-income countries. Glob. Food Sec. 26, 100372 (2020).

10. P. J. Gerber, T. V. Vellinga, C. Opio, H. Steinfeld., Productivity gains and greenhouse gas emissions intensity in dairy systems. Livest. Sci. 139, 100-108 (2011).

11. W. J. Ripple et al. Ruminants, climate change and climate policy. Nat. Clim. Change 4, 2-5 (2014).

12. M. Herrero et al., Greenhouse gas mitigation potentials in the livestock sector. Nat. Clim. Change 6, 452-461 (2016).

13. J. B. Veneman, E. R. Saetnan, A. J. Clare, C. J. Newbold, MitiGate; an online meta-analysis database for quantification of mitigation strategies for enteric methane emissions. Sci. Total Environ. 572, 1166-1174 (2016).

14. IPCC, 2006 IPCC Guidelines for National Greenhouse Gas Inventories, Volume 4: Agriculture, Forestry and Other Land Use (eds H. S. Eggleston, L. Buendia, K. Miwa, T. Ngara, K. Tanabe) Ch.10, 1-89 (IGES, Hayama 2006).

15. International Chemical Safety Card: 0392 - Bromocholoromethane (2017). World Health Organization \& International Labor Organization (2017). Available at 
https://www.ilo.org/dyn/icsc/showcard.display?p_lang=en\&p_card_id=0392\&p_v ersion $=2$

16. D. von Soosten, U. Meyer, G. Flachowsky, S. Dänicke, Dairy Cow Health and Greenhouse Gas Emission Intensity. Dairy 1, 20-29. (2020).

17. U. Ermler, W. Grabarse, S. Shima, M. Goubeaud, R. Thauer, Crystal structure of methyl-coenzyme M reductase: The Key Enzyme of Biological Methane Formation. Science 278, 1457-1462 (1997).

18. S. H. Kim et al., Effects of 3-nitrooxypropanol on enteric methane production, rumen fermentation, and feeding behavior in beef cattle fed a high-forage or highgrain diet. J. Anim. Sci. 97, 2687-2699 (2019).

19. S. van Gastelen et al., 3-Nitrooxypropanol decreases methane emissions and increases hydrogen emissions of early lactation dairy cows, with associated changes in nutrient digestibility and energy metabolism. J. Dairy Sci. 103, 80748093 (2020).

20. A. N. Hristov, A. Melgar, Short communication: Relationship of dry matter intake with enteric methane emission measured with the GreenFeed system in dairy cows receiving a diet without or with 3-nitrooxypropanol. Animal 14, s484-s490 (2020).

21. J. Dijkstra, A. Bannink, J. France, E. Kebreab, S. van Gastelen, Short communication: Antimethanogenic effects of 3-nitrooxypropanol depend on supplementation dose, dietary fiber content, and cattle type. J. Dairy Sci. 101, 9041-9047 (2018).

22. C. K. Reynolds et al., Effects of 3-nitrooxypropanol on methane emission, digestion, and energy and nitrogen balance of lactating dairy cows. J. Dairy Sci. 97, 3777-3789 (2014).

23. S. Muetzel et al., Conference abstract in Proceedings of the 7th International Greenhouse Gas and Animal Agriculture Conference. Iguassu Falls, Brazil (eds A. Berndt, L. G. Pereira Ribeiro, A. L. Abdala), 81 (Embrapa Southeast Livestock, São Carlos, SP, 2019).

24. D. Vyas et al., The combined effects of supplementing monensin and 3nitrooxypropanol on methane emissions, growth rate, and feed conversion efficiency in beef cattle fed high-forage and high-grain diets. J. Anim. Sci. 96, 2923-2938 (2018).

25. B. Roque et al., Red seaweed (Asparagopsis taxiformis) supplementation reduces enteric methane by over 80 percent in beef steers. bioRxiv; 2020. DOI: 10.1101/2020.07.15.204958

26. H. Stefenoni et al., Effects of Asparagopsis taxiformis and oregano leaves on methane emission, rumen fermentation, and lactational performance of dairy cows. J. Dairy Sci. 103, 158 (2020). 
27. Bromoform Fact Sheet, US Environmental Protection Agency (2000)._Available at https://www.epa.gov/sites/production/files/2016-09/documents/bromoform.pdf

28. L. Machado et al., Identification of bioactives from the red seaweed Asparagopsis taxiformis that promote antimethanogenic activity in vitro. J. Appl. Phycol. 28, 3117-3126 (2016).

29. M. A. Navarro et al., Airborne measurements of organic bromine compounds in the Pacific tropical tropopause layer. Proc. Natl. Acad. Sci. U.S.A 112, 1378913793 (2015).

30. M. Eugène, D. Massé, J. Chiquette, C. Benchaar, Meta-analysis on the effects of lipid supplementation on methane production in lactating dairy cows. Can. J. Anim. Sci. 88, 331-337 (2008).

31. H. Liu, V. Vaddella, D. Zhou, Effects of chestnut tannins and coconut oil on growth performance, methane emission, ruminal fermentation, and microbial populations in sheep. J. Dairy Sci. 94, 6069-6077 (2011).

32. E. Jordan et al., Effect of refined coconut oil or copra meal on methane output and on intake and performance of beef heifers. J. Anim. Sci. 84, 162-170 (2006).

33. D. L. Palmquist, T. C. Jenkins, A 100-Year Review: Fat feeding of dairy cows. J. Dairy Sci. 100, 10061-10077 (2017).

34. D. J., Schauff, J. H. Clark, Effects of feeding diets containing calcium salts of long-chain fatty acids to lactating dairy cows. J. Dairy Sci. 75, 2990-3002 (1992).

35. W. Wang et al., Greenhouse gas mitigation in Chinese agriculture: Distinguishing technical and economic potentials. Glob. Environ. Change 26, 53-62 (2014).

36. M. Doreau, L. Bamière, S. Pellerin, M. Lherm, M. Benoit, Mitigation of enteric methane for French cattle: Potential extent and cost of selected actions. Anim. Prod. Sci. 54, 1417-1422 (2014)

37. C. E. van Middelaar, J. Dijkstra, P. B. M. Berentsen, I. J. M. De Boer, Costeffectiveness of feeding strategies to reduce greenhouse gas emissions from dairy farming. J. Dairy Sci. 97, 2427-2439 (2014).

38. M. Doreau, A. Meynadier, V. Fievez, A. Ferlay, Ruminal metabolism of fatty acids: modulation of polyunsaturated, conjugated, and trans fatty acids in meat and milk. (eds R. R. Watson, F. De Meester) Handbook of Lipids in Human Function Ch 19 - 521-542 (AOCS Press, 2016).

39. E. M. Ungerfeld, Metabolic hydrogen flows in rumen fermentation: principles and possibilities of interventions. Front. Microbiol.11, 595 (2020).

40. X. Y. Feng, et al., Antimethanogenic effects of nitrate supplementation in cattle: A meta-analysis. J. Dairy. Sci. 103, 11375-11385 (2020).

41. L. Li et al., Effect of added dietary nitrate and elemental sulfur on wool growth and methane emission of Merino lambs. Anim. Prod. Sci. 53, 1195-1201 (2013). 
42. S. Zijderveld et al., Persistency of methane mitigation by dietary nitrate supplementation in dairy cows. J. Dairy Sci. 94, 4028-4038 (2011).

43. P. A. Farra, L. D. Satter, Manipulation of ruminal fermentation. III. Effect of nitrate on ruminal volatile fatty acid production and milk composition. J. Dairy Sci. 54, 1018-1024 (1971).

44. A. R Alaboudi, G. A. Jones, Effect of acclimation to high nitrate intakes on some rumen fermentation parameters in sheep. Can. J. Anim. Sci. 65, 841-849 (1985).

45. S. O. Petersen et al., Dietary nitrate for methane mitigation leads to nitrous oxide emissions from dairy cows. J. Environ. Qual. 44, 1063-1070 (2015).

46. H. Liu et al., Effects of lespedeza condensed tannins alone or with monensin, soybean oil, and coconut oil on feed intake, growth, digestion, ruminal methane emission, and heat energy by yearling alpine doelings. J. Anim. Sci. 97, 885-899 (2019).

47. D. A. Häring et al., Tanniferous forage plants: Agronomic performance, palatability and efficacy against parasitic nematodes in sheep. Renew. Agric. Food Syst. 23, 19-29 (2008).

48. J. Zhang et al., Effect of different tannin sources on nutrient intake, digestibility, performance, nitrogen utilization, and blood parameters in dairy cows. Animals $\mathbf{9}$, 507 (2019).

49. P. Huhtanen, M. Rinne, J. Nousiainen, A meta-analysis of feed digestion in dairy cows. 2. The effects of feeding level and diet composition on digestibility. $J$. Dairy Sci. 92, 5031-5042 (2009).

50. GLEAM 2.0 - Assessment of greenhouse gas emissions and mitigation potential. Food and Agriculture Organization of the United Nations (FAO). http://www.fao.org/gleam/results/en/ (2017).

51. N. Abdela, Sub-acute Ruminal Acidosis (SARA) and its Consequence in Dairy Cattle: A Review of Past and Recent Research at Global Prospective. Achievements in the Life Sciences, 10, 187-196 (2016).

52. J. P. Goopy et al., Severe below-maintenance feed intake increases methane yield from enteric fermentation in cattle. Br. J. Nutr. 123, 1239-1246 (2020).

53. A. N. Hristov et al., Special topics - Mitigation of methane and nitrous oxide emissions from animal operations: III. A review of animal management mitigation options. J. Anim. Sci. 91, 5095-5113 (2013).

54. FAO \& New Zealand Agricultural Greenhouse Gas Research Centre. Low Emissions Development of the Beef Cattle Sector in Uruguay - Reducing Enteric Methane for Food Security and Livelihoods. (FAO/NZAGGRC, Rome, 2017).

55. R. Demanet, M. L. Mora, M. Á. Herrera, H. Miranda, J. M. Barea, Seasonal variation of the productivity and quality of permanent pastures in Andisols of temperate regions. J. Soil Sci. Plant Nutr. 15, 111-128 (2015). 
56. F. Montes et al., Special topics - Mitigation of methane and nitrous oxide emissions from animal operations: II. A review of manure management mitigation options. J. Anim. Sci. 91, 5070-5094 (2013).

57. P. Huhtanen, A. R. Bayat, P. Lund, A. Hellwing, M. Weisbjerg, Short communication: Variation in feed efficiency hampers use of carbon dioxide as a tracer gas in measuring methane emissions in on-farm conditions. J. Dairy Sci. 103, 9090-9095 (2020).

58. K. J. Hammond et al., Review of current in vivo measurement techniques for quantifying enteric methane emission from ruminants. Anim. Feed Sci. Technol. 219, 13-30 (2016).

59. M. Borenstein, L. V. Hedges, J. P. T. Higgins, H. R. Othstein, Introduction to Meta-analysis. (Chichester, John Wiley \& Sons, 2009).

60. J. O.Friedrich, N. K. Adhikari, J. Beyene, The ratio of means method as an alternative to mean differences for analyzing continuous outcome variables in meta-analysis: A simulation study. BMC Med. Res. Methodol. 8, 32 (2008).

61. S. Holm, A simple sequentially rejective multiple test procedure. Scand. J. Stat. 6, 65-70 (1979). 


\section{FIGURES AND TABLES}

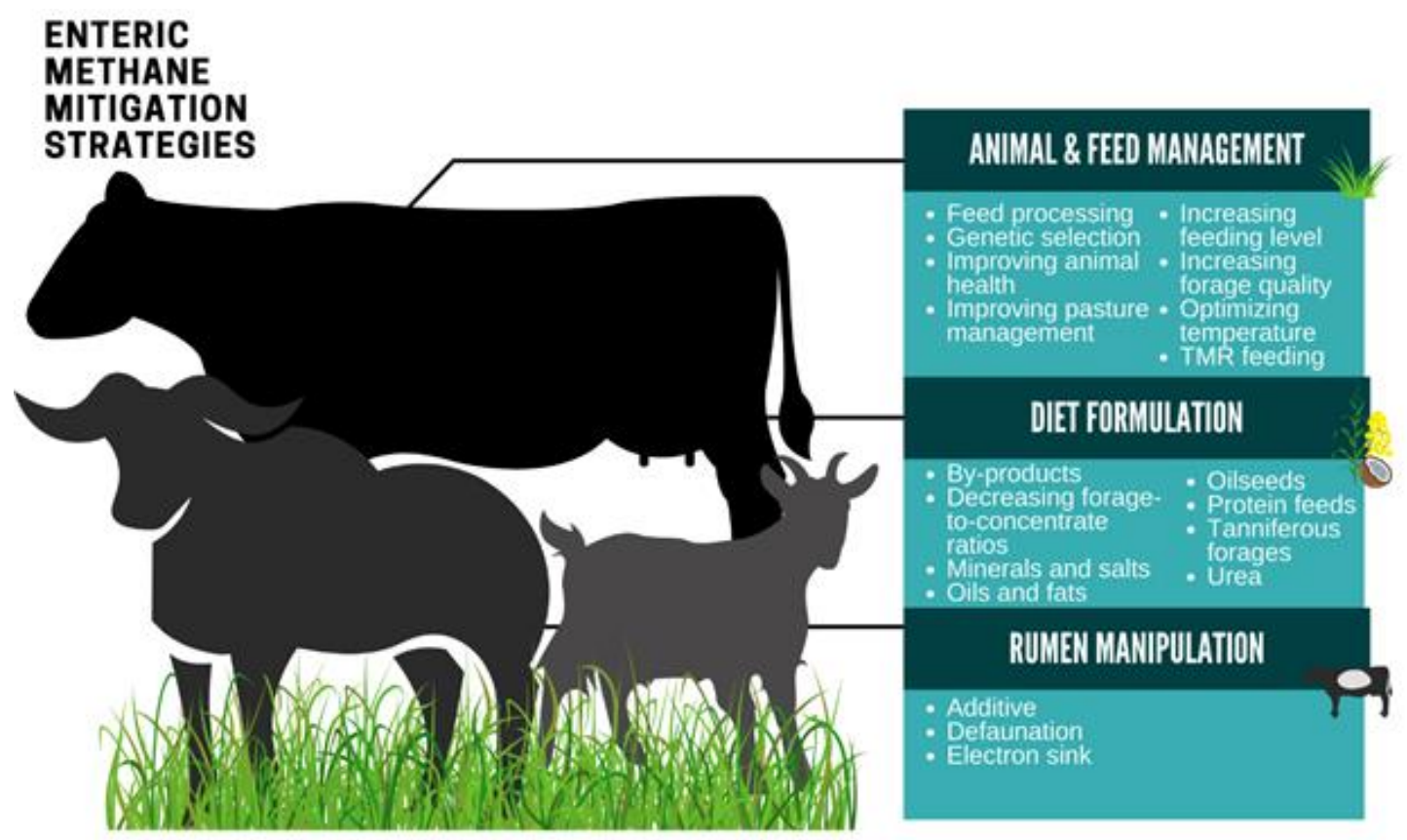

Figure 1. Studied enteric methane mitigation strategies. For a complete list of strategies, see supplementary Table S2. 
A

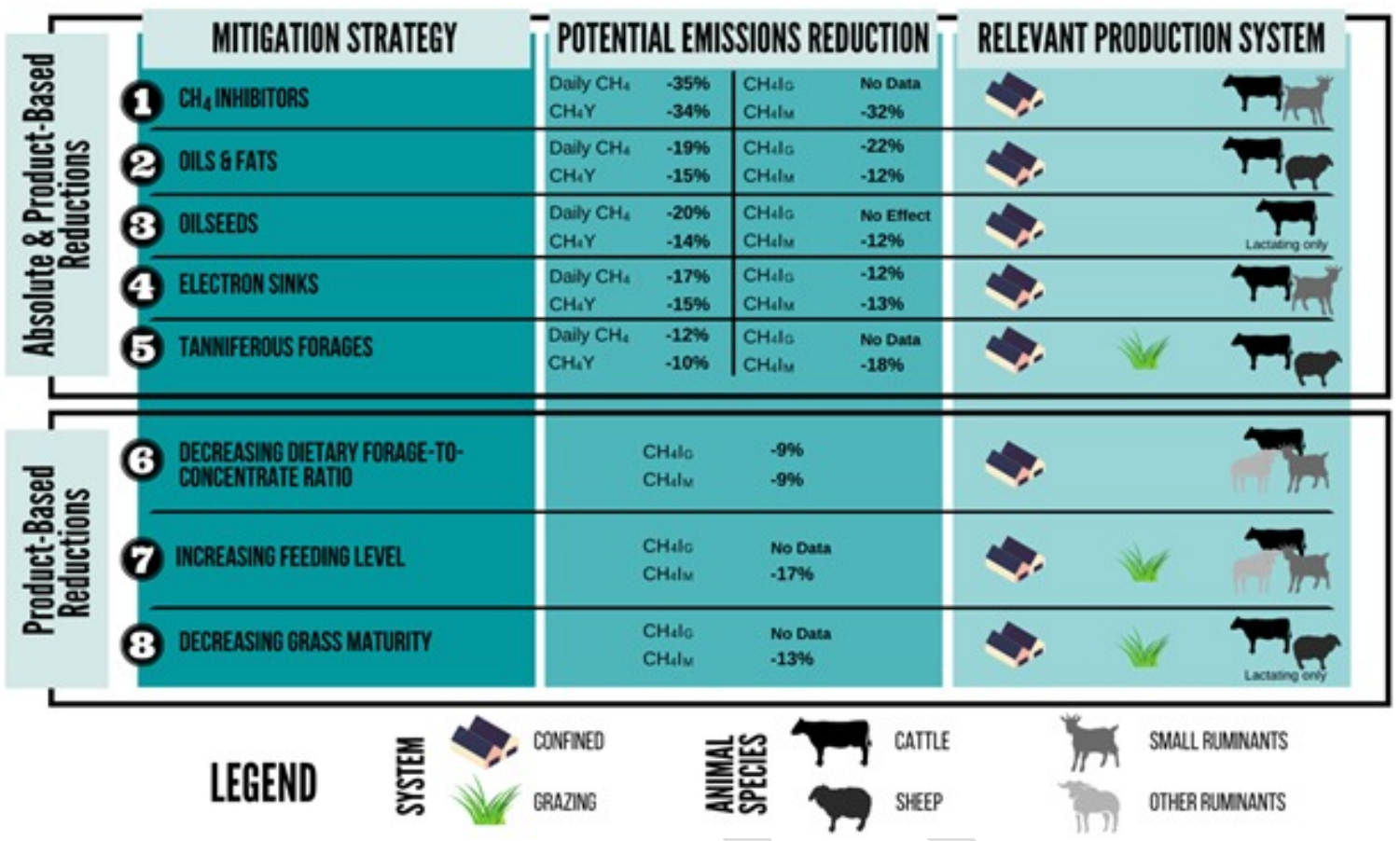

B

\begin{tabular}{|c|c|c|c|c|}
\hline \multirow{2}{*}{ LITIGATION STRATEGY } & \multicolumn{4}{|c|}{ Relative Treatment Effect on Animal Performance } \\
\hline & INTAKE & DIGESTIBILITY & GAIN & MILK \\
\hline 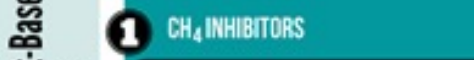 & No Effect & No Effect & No Effect & No Effect \\
\hline OIISgFats & $-6 \%$ & -49 & No Effect & No Effect \\
\hline 흐를 3 OllseENS & No Effect & $-8 \%$ & $.13 \%$ & No Effect \\
\hline 容 4 EleCtron Sinks & .296 & No Effect & No Effect & $+3 \%$ \\
\hline (5) TANAFEROUS FORAGES & No Effect & .796 & No Effect & No Effect \\
\hline 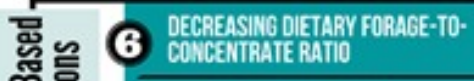 & $+9 \%$ & No Effect & $+21 \%$ & $+17 \%$ \\
\hline 竞尊 7 INCREASING FEEDING LEVEL & $+58 \%$ & .796 & $+162 \%$ & $+17 \%$ \\
\hline 흔효 8 DECREASIIG GRASS MATURITY & No Effect & $+15 \%$ & No Data & $+9 \%$ \\
\hline
\end{tabular}

Figure 2. Effective mitigation strategies and their effect on methane $\left(\mathrm{CH}_{4}\right)$ emission

(a) and animal performance metrics (b). Daily $\mathrm{CH}_{4}=$ daily $\mathrm{CH}_{4}$ emission $\left(\mathrm{g}\right.$ animal ${ }^{-1}$ day $\left.^{-1}\right)$; $\mathrm{CH}_{4} \mathrm{Y}=\mathrm{CH}_{4}$ yield $\left(\mathrm{CH}_{4} \mathrm{~g}\right.$ per $\mathrm{kg}$ of dry matter intake), $\mathrm{CH}_{4} \mathrm{I}_{\mathrm{G}}=\mathrm{CH}_{4}$ emission intensity for weight gain $(\mathrm{g}$ $\mathrm{CH}_{4}$ per kg of weight gain for growing animals), $\mathrm{CH}_{4} \mathrm{I}_{\mathrm{M}}=\mathrm{CH}_{4}$ emission intensity for milk $\left(\mathrm{CH}_{4} \mathrm{~g}\right.$ per $\mathrm{kg}$ of milk), Intake $=$ dry matter intake $\left(\mathrm{kg} \mathrm{d}^{-1}\right)$; Digestibility $=$ apparent digestibility of neutral detergent fiber $(\%)$; Gain = average daily gain $\left(\mathrm{kg} \mathrm{d}^{-1}\right)$, Milk $=$ milk yield $\left(\mathrm{kg} \mathrm{d}^{-1}\right)$; when numeric values are shown a significant effect was observed (adjusted $P<0.05$ ) and no effect when adjusted $P \geq 0.05$. 


\section{SUPPLEMENTARY INFORMATION SUPPLEMENATARY TABLES}

Supplementary Table 1. Publications included in this meta-analysis.

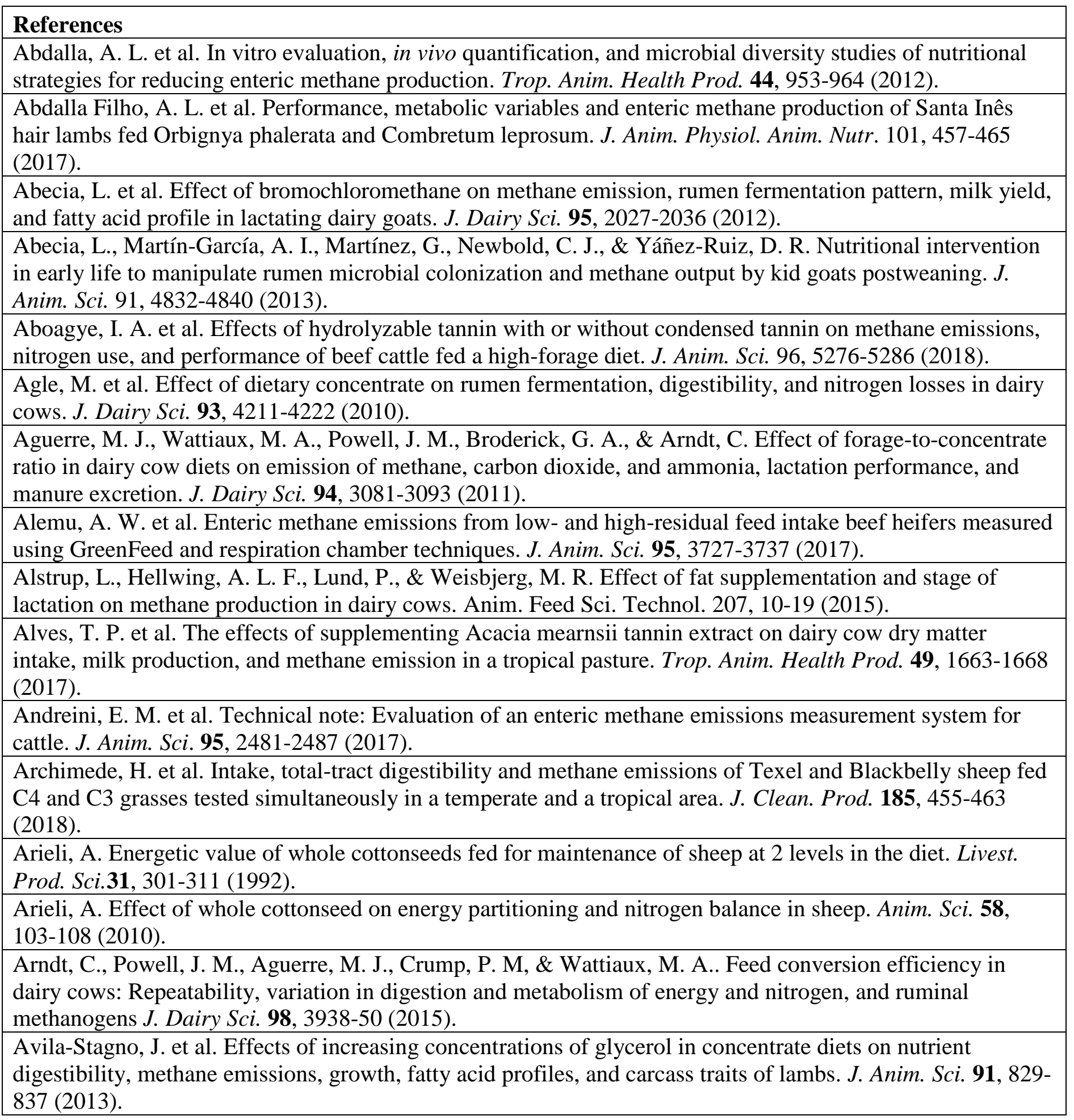


Azlan, P. M. et al. Aspergillus terreus treated rice straw suppresses methane production and enhances feed digestibility in goats. Trop. Anim. Health Prod. 50, 565-571 (2018).

Barbero, R. P. et al. Combining Marandu grass grazing height and supplementation level to optimize growth and productivity of yearling bulls. Anim. Feed Sci. Technol. 209, 110-118 (2015).

Barbosa, A. L. et al. Intake, digestibility, growth performance, and enteric methane emission of Brazilian semiarid non-descript breed goats fed diets with different forage to concentrate ratios. Trop. Anim. Health Prod. 50, 283-289 (2018).

Bayaru, A. R. et al. Effect of fumaric acid on methane production, rumen fermentation and digestibility of cattle fed roughage alone. Anim. Sci. J. 72, 139-146 (2001).

Bayat, A. R. et al. Effect of camelina oil or live yeasts (Saccharomyces cerevisiae) on ruminal methane production, rumen fermentation, and milk fatty acid composition in lactating cows fed grass silage diets. $J$. Dairy Sci. 98, 3166-3181 (2015).

Bayat, A. R. et al. Dietary forage to concentrate ratio and sunflower oil supplement alter rumen fermentation, ruminal methane emissions, and nutrient utilization in lactating cows. Transl. Anim. Sci. 1, 277-286 (2017).

Bayat, A. R. et al. Plant oil supplements reduce methane emissions and improve milk fatty acid composition in dairy cows fed grass silage-based diets without affecting milk yield. J. Dairy Sci 101, 1136-1151 (2018).

Beauchemin, K. A. et al. Methane abatement strategies for cattle: Lipid supplementation of diets. Can. J. Anim. Sci. 87, 431-440 (2007).

Beauchemin, K. A., \& McGinn, S. M. Enteric methane emissions from growing beef cattle as affected by diet and level of intake. Can. J. Anim. Sci. 86, 401-408 (2006).

Beauchemin, K. A., \& McGinn, S. M. Methane emissions from beef cattle: Effects of fumaric acid, essential oil, and canola oil. J. Anim. Sci. 84, 1489-1496 (2006).

Beauchemin, K. A., McGinn, S. M., Martinez, T. F., \& McAllister, T. A. Use of condensed tannin extract from quebracho trees to reduce methane emissions from cattle. J. Anim. Sci. 85, 1990-1996 (2007).

Belyea, R. L., Marin, P. J., \& Sedgwick, H. T. Utilization of chopped and long alfalfa by dairy heifers. $J$. Dairy Sci. 68, 1297-1301 (1985).

Benchaar, C. et al. Effects of increasing amounts of corn dried distillers grains with solubles in dairy cow diets on methane production, ruminal fermentation, digestion, $\mathrm{N}$ balance, and milk production. J. Dairy Sci. 96, 2413-2427 (2013).

Benchaar, C., Hassanat, F., \& Petit, H. V. Dose-response to eugenol supplementation to dairy cow diets: Methane production, $\mathrm{N}$ excretion, ruminal fermentation, nutrient digestibility, milk production, and milk fatty acid profile. Anim. Feed Sci. Technol. 209, 51-59 (2015).

Benchaar, C., Hassanat, F., Martineau, R., \& Gervais, R. Linseed oil supplementation to dairy cows fed diets based on red clover silage or corn silage: Effects on methane production, rumen fermentation, nutrient digestibility, N balance, and milk production. J. Dairy Sci. 98, 7993-8008 (2015).

Berchielli, T. et al. In 40 a Reuniao Anual da Sociedade Brasileira de Zootecnia (Embrapa, Santa Maria, 2003).

Bharanidharan, R. et al. Ruminal methane emissions, metabolic, and microbial profile of Holstein steers fed forage and concentrate, separately or as a total mixed ration. PLoS ONE 13, 19 (2018).

Bird, S. H., Hegarty, R. S., \& Woodgate, R. Persistence of defaunation effects on digestion and methane production in ewes. Anim. Prod. Sci. 48, 152-155. (2008).

Birkelo, C. P., Johnson, D. E., \& Ward, G. M. Net energy value of ammoniated wheat straw. J. Anim. Sci. 63, 2044-2052 (1986).

Biswas, A. A. et al. Effects of illite supplementation on in vitro and in vivo rumen fermentation, microbial population and methane emission of Hanwoo steers fed high concentrate diets. Anim. Sci. J. 89, 114-121 (2018). 
Boadi, D. A. et al. Effect of low and high forage diet on enteric and manure pack greenhouse gas emissions from a feedlot. Can. J. Anim. Sci. 84, 445-453 (2004).

Boadi, D. A., \& Wittenberg, K. M. Methane production from dairy and beef heifers fed forages differing in nutrient density using the sulphur hexafluoride (SF6) tracer gas technique. Can. J. Anim. Sci. 82, 201-206 (2002).

Boadi, D. A., Wittenberg, K. M., \& McCaughey, W. Effects of grain supplementation on methane production of grazing steers using the sulphur (SF6) tracer gas technique. Can. J. Anim. Sci. 82, 151-157 (2002).

Boland, T. M. et al. The effect of pasture pregrazing herbage mass on methane emissions, ruminal fermentation, and average daily gain of grazing beef heifers. J. Anim. Sci. 91, 3867-3874 (2013).

Bouchard, K. et al. Comparison of feed intake, body weight gain, enteric methane emission and relative abundance of rumen microbes in steers fed sainfoin and lucerne silages under western Canadian conditions. Grass Forage Sci.70, 116-129 (2015).

Bougouin, A. et al. Effects of carbohydrate type or bicarbonate addition to grass silage-based diets on enteric methane emissions and milk fatty acid composition in dairy cows. J. Dairy Sci.101, 6085-6097 (2018).

Branco, A. F. et al. Effect of technical cashew nut shell liquid on rumen methane emission and lactation performance of dairy cows. J. Dairy Sci. 98, 4030-4040 (2015).

Brask, M. et al. Methane production and digestion of different physical forms of rapeseed as fat supplements in dairy cows. J. Dairy Sci.96, 2356-2365 (2013).

Brask, M., Lund, P., Hellwing, A. L. F., Poulsen, M., \& Weisbjerg, M. R. Enteric methane production, digestibility and rumen fermentation in dairy cows fed different forages with and without rapeseed fat supplementation. Anim. Feed Sci. Technol. 184, 67-79 (2013).

Brown, E. G. et al. Effects of oral nitroethane administration on enteric methane emissions and ruminal fermentation in cattle. Anim. Feed Sci. Technol. 166, 275-281 (2011).

Caetano, M., Wilkes, M., Pitchford, W., Lee, S., \& Hynd, P. Efficacy of methane-reducing supplements in beef cattle rations. Anim. Prod. Sci. 56, 276-281 (2015).

Cammell, S. B. et al. The efficiency of energy utilization in growing cattle consuming fresh perennial ryegrass (Lolium perenne cv. Melle) or white clover (Trifolium repens cv. Blanca). Br. J. Nutr. 55, 669-680 (1986).

Cammell, S. B., Sutton, J. D., Beever, D. E., Humphries, D. J., \& Phipps, R. H. The effect of crop maturity on the nutritional value of maize silage for lactating dairy cows 1. Energy and nitrogen utilization. Anim. Sci. 71, 381-390 (2000).

Cao, Y., Takahashi, T., Horiguchi, K. I., Yoshida, N., \& Cai, Y. Methane emissions from sheep fed fermented or non-fermented total mixed ration containing whole-crop rice and rice bran. Anim. Feed Sci. Technol. 157, 72-78 (2010).

Carulla, J. E., Kreuzer, M., Machmüller, A., \& Hess, H. D. Supplementation of Acacia mearnsii tannins decreases methanogenesis and urinary nitrogen in forage-fed sheep. Crop Pasture Sci. 56, 961-970 (2005).

Castillo-Lopez, E. et al. The effect of regular or reduced-fat distillers grains with solubles on rumen methanogenesis and the rumen bacterial community. J. Appl. Microbiol. 123, 1381-1395 (2017).

Castro-Montoya, J. et al. In vivo and in vitro effects of a blend of essential oils on rumen methane mitigation. Livest. Sci.180, 134-142 (2015).

Chandramoni, Jadhao, S., Tiwari, C. M., \& Y Khan, M. Energy metabolism with particular reference to methane production in Muzaffarnagari sheep fed rations varying in roughage to concentrate ratio. Anim. Feed Sci. Technol. 83, 287-300 (2000).

Chandramoni, Jadhao, S., Tiwari, C. M., Haque, N., Murarilal, \& Khan, M. Y. Energy Metabolism and methane production in faunated and defaunated sheep fed two diets with same concentrate to roughageratio (70:30) but varying in composition. Asian Australas J. Anim. Sci. 14, 1238-1244 (2001). 
Chaokaur, A., Nishida, T., Phaowphaisal, I., \& Sommart, K. Effects of feeding level on methane emissions and energy utilization of Brahman cattle in the tropics. Agric. Ecosyst. Environ. 199, 225-230 (2015).

Chaves, A. V. et al. Effect of pasture type (alfalfa vs. grass) on methane and carbon dioxide production by yearling beef heifers. Can. J. Anim. Sci. 86, 409-418 (2006).

Chethan, K. P., Verma, A. K., \& Singh, P. Effect of fumaric acid supplementation on methanogenesis and rumen fermentation in Barbari goats. Indian J. Anim. Sci. 83, 63-66 (2013).

Chong, L., Zhuping, Z., Tongjun, G., Yongming, L., \& Hongmin, D. Changes in methane emission, rumen fermentation, and methanogenic community in response to silage and dry cornstalk diets. J. Basic Microbiol. 54, 521-530 (2014).

Chung, Y.-H. et al. A fibrolytic enzyme additive for lactating Holstein cow diets: Ruminal fermentation, rumen microbial populations, and enteric methane emissions. J. Dairy Sci. 95, 1419-1427 (2012).

Chung, Y.-H. et al. Enteric methane emission, diet digestibility, and nitrogen excretion from beef heifers fed sainfoin or alfalfa. J. Anim. Sci. 91, 4861-4874 (2013).

Chung, Y.-H., He, M. L., McGinn, S. M., McAllister, T. A., \& Beauchemin, K. A. Linseed suppresses enteric methane emissions from cattle fed barley silage, but not from those fed grass hay. Anim. Feed Sci.

Technol.166, 321-329 (2011).

Chung, Y.-H., Walker, N. D., McGinn, S. M., \& Beauchemin, K. A. Differing effects of 2 active dried yeast (Saccharomyces cerevisiae) strains on ruminal acidosis and methane production in nonlactating dairy cows. $J$. Dairy Sci. 94, 2431-2439 (2011).

Chuntrakort, P. et al. The effect of dietary coconut kernels, whole cottonseeds and sunflower seeds on the intake, digestibility and enteric methane emissions of Zebu beef cattle fed rice straw based diets. Livest.

Sci.161, 80-89 (2014).

Cole, N. A., \& McCroskey, J. E. Effects of hemiacetal of chloral and starch on the performance of beef steers. J. Anim. Sci. 41, 1735-1741 (1975).

Congio, G. F. S. et al. Strategic grazing management towards sustainable intensification at tropical pasturebased dairy systems. Sci. Total Environ. 636, 872-880 (2018).

Cosgrove, G. P. et al. The effect of oils fed to sheep on methane production and digestion of ryegrass pasture. Anim. Prod. Sci.48, 189-192 (2008).

Crossland, W. L. et al. Effects of active dry yeast on ruminal $\mathrm{pH}$ characteristics and energy partitioning of finishing steers under thermoneutral or heat-stressed environment. J. Anim. Sci. 96, 2861-2876 (2018).

Cushnahan, A., Mayne, C. S., \& Unsworth, E. F. Effects of ensilage of grass on performance and nutrient utilization by dairy cattle 2. Nutrient metabolism and rumen fermentation. Anim. Sci.60, 347-359 (1995).

Czerkawski, J. W., Blaxter, K. L., \& Wainman, F. W. The effect of linseed oil and of linseed oil fatty acids incorporated in the diet on the metabolism of sheep. Br. J. Nutr.20, 485-494 (1966).

Da Silveira Pontes, L. et al.. Performance and methane emissions by beef heifer grazing in temperate pastures and in integrated crop-livestock systems: the effect of shade and nitrogen fertilization. Agric. Ecosyst.

Environ. 253, 90-97 (2018).

De Oliveira, S. G. et al. Effect of tannin levels in sorghum silage and concentrate supplementation on apparent digestibility and methane emission in beef cattle. Anim. Feed Sci. Technol. 135, 236-248 (2007).

De Raphélis-Soissan, V. et al. Use of nitrate and Propionibacterium acidipropionici to reduce methane emissions and increase wool growth of Merino sheep. Anim. Prod. Sci.54, 1860-1866 (2014).

De Raphélis-Soissan, V. et al. Use of nitrate and Propionibacterium acidipropionici to reduce methane emissions and increase wool growth of Merino sheep. Anim. Prod. Sci. 54, 1860-18661 (2014).

Delfino, J., Mathison, G. W., \& Smith, M. W. Effect of lasalocid on feedlot performance and energy partitioning in cattle. J. Anim. Sci., 66, 136-150 (1988).

Delgado, D. C. et al. Effect of the coconut oil on the consumption, digestion of nutrients and methane production in sheep fed with forage and concentrate. Cuban J. Agric. Sci.46, 381-384 (2012). 
Delgado, D. C. et al. Feeding of tropical trees and shrub foliages as a strategy to reduce ruminal methanogenesis: studies conducted in Cuba. Trop. Anim. Health Prod. 44, 1097-1104 (2012).

Delgado, D. C., Galindo, J., Cairo, J., Orta, I., \& Dorta, N. Supplementation with foliage of L. leucocephala. Its effect on the apparent digestibility of nutrients and methane production in sheep. Cuba. J. Agric. Sci. 47, (2013).

Deng, K. D. et al. Ruminal fermentation, nutrient metabolism, and methane emissions of sheep in response to dietary supplementation with Bacillus licheniformis. Anim. Feed Sci. Technol. 241, 38-44 (2018).

Denman, S. E., Tomkins, N. W., \& McSweeney, C. S. Quantitation and diversity analysis of ruminal methanogenic populations in response to the antimethanogenic compound bromochloromethane. FEMS Microbiol. Ecol. 62, 313-322 (2007).

DeRamus, H. A., Clement, T. C., Giampola, D. D., \& Dickison, P. C. Methane emissions of beef cattle on forages. J. Environ. Qual. 32, 269-277 (2003).

Ding, X. et al. Reducing methane emissions and the methanogen population in the rumen of Tibetan sheep by dietary supplementation with coconut oil. Trop. Anim. Health Prod. 44, 1541-1545 (2012).

Ding, X. Z., Long, R. J., Kreuzer, M., Mi, J. D., \& Yang, B. Methane emissions from yak (Bos grunniens) steers grazing or kept indoors and fed diets with varying forage:concentrate ratio during the cold season on the Qinghai-Tibetan Plateau. Anim. Feed Sci. Technol. 162, 91-98 (2010).

Dini, Y. et al. Using highly nutritious pastures to mitigate enteric methane emissions from cattle grazing systems in South America. Anim. Prod. Sci.58, 2329-2334 (2018).

Doreau, M. et al. Enteric methane production and greenhouse gases balance of diets differing in concentrate in the fattening phase of a beef production system. J. Anim. Sci. 89, 2518-2528 (2011).

Doreau, M., Ferlay, A., Rochette, Y., \& Martin, C. Effects of dehydrated lucerne and soya bean meal on milk production and composition, nutrient digestion, and methane and nitrogen losses in dairy cows receiving two different forages. Animal 8, 420-430 (2014).

Dos Santos Pedreira, M. et al. Methane emissions and estimates of ruminal fermentation parameters in beef cattle fed different dietary concentrate levels. R. Bras. Zootec. 42, 592-598 (2013).

Drehmel, O. R. et al. The influence of fat and hemicellulose on methane production and energy utilization in lactating Jersey cattle. J. Dairy Sci.101, $7892-7906$ (2018).

Duthie, C. A. et al. The impact of divergent breed types and diets on methane emissions, rumen characteristics and performance of finishing beef cattle. Animal 11, 1762-1771 (2017).

Duthie, C. A. et al. The effect of dietary addition of nitrate or increase in lipid concentrations, alone or in combination, on performance and methane emissions of beef cattle. Animal 12, 280-287 (2018).

Duthie, C. A., Rooke, J. A., Hyslop, J. J., \& Waterhouse, A. Methane emissions from two breeds of beef cows offered diets containing barley straw with either grass silage or brewers' grains. Animal 9, 1680-1687 (2015).

Ebert, P. J. et al. Effect of condensed tannin extract supplementation on growth performance, nitrogen balance, gas emissions, and energetic losses of beef steers. J. Anim. Sci. 95, 1345-1355 (2017).

El-Zaiat, H. M. et al. Encapsulated nitrate and cashew nut shell liquid on blood and rumen constituents, methane emission, and growth performance of lambs. J. Anim. Sci. 92, 2214-2224 (2014).

Ferris, C. P., Gordon, F. J., Patterson, D. C., Porter, M. G., \& Yan, T. The effect of genetic merit and concentrate proportion in the diet on nutrient utilization by lactating dairy cows. J. Agric. Sci.132, 483-490 (1999).

Ferris, C. P., McCoy, M. A., Lennox, S. D., Catney, D. C., \& Gordon, F. J. Nutrient utilisation and energy balance associated with two contrasting winter milk production systems for high genetic merit autumn calving dairy cows. Irish J. Agric. Food Res. 41, 55-70 (2002). 
Fitzsimons, C., Kenny, D. A., Deighton, M. H., Fahey, A. G., \& McGee, M. Methane emissions, body composition, and rumen fermentation traits of beef heifers differing in residual feed intake. J. Anim. Sci. 91, 5789-5800 (2013).

Foley, P. A. et al. Effect of DL-malic acid supplementation on feed intake, methane emissions, and performance of lactating dairy cows at pasture. J. Dairy Sci. 92, 3258-3264 (2009).

Foley, P. A., Kenny, D. A., Callan, J. J., Boland, T. M., \& O’mara, F. P. Effect of DL-malic acid supplementation on feed intake, methane emission, and rumen fermentation in beef cattle. J. Anim. Sci. 87, 1048-1057 (2009).

Foth, A. J. et al. Energy content of reduced-fat dried distillers grains with solubles for lactating dairy cows. $J$. Dairy Sci. 98, 7142-7152 (2015).

Fraser, M. D., Fleming, H. R., \& Moorby, J. M. Traditional vs modern, role of breed type in determining enteric methane emissions from cattle grazing as part of contrasting grassland-based systems. PLoS One 9, 9 (2014).

Fredeen, A., Juurlink, S., Main, M., Astatkie, T., \& Martin, R. C. Implications of dairy systems on enteric methane and postulated effects on total greenhouse gas emission. Animal 7, 1875-1883 (2013).

Freitas, D. S. et al. Unconventional Vegetable Oils for a Reduction of Methanogenesis and Modulation of Ruminal Fermentation. Front. Vet. Sci. 5, 9 (2018).

Garg, M. R. et al. Effects of feeding nutritionally balanced rations on animal productivity, feed conversion efficiency, feed nitrogen use efficiency, rumen microbial protein supply, parasitic load, immunity and enteric methane emissions of milking animals under field conditions. Anim. Feed Sci. Technol. 179, 24-35 (2013).

Garg, M. R., Sherasia, P. L., Phondba, B. T., \& Hossain, S. A. Effect of feeding a balanced ration on milk production, microbial nitrogen supply and methane emissions in field animals. Anim. Prod. Sci. 54, 16571661 (2014).

Gidlund, H. et al. Milk production and methane emissions from dairy cows fed a low or high proportion of red clover silage and an incremental level of rapeseed expeller. Livest. Sci. 197, 73-81 (2017).

Gidlund, H., Hetta, M., Krizsan, S. J., Lemosquet, S., \& Huhtanen, P. Effects of soybean meal or canola meal on milk production and methane emissions in lactating dairy cows fed grass silage-based diets. J. Dairy Sci. 98, 8093-8106 (2015).

Gill, F. L. et al. Analysis of archaeal ether lipids in bovine faeces. Anim. Feed Sci. Technol. 166, 87-92 (2011).

Gordon, F. J. et al. The influence of genetic index for milk production on the response to complete diet feeding and the utilization of energy and nitrogen. Anim. Sci 61, 199-210 (1995).

Gordon, F. J., Porter, M. G., Mayne, C. S., Unsworth, E. F., \& Kilpatrick, D. J. Effect of forage digestibility and type of concentrate on nutrient utilization by lactating dairy cattle. J. Dairy Res. 62, 15-15 (1995).

Grainger, C. et al. Use of monensin controlled-release capsules to reduce methane emissions and improve milk production of dairy cows offered pasture supplemented with grain. J. Dairy Sci. 91, 1159-1165 (2008). Grainger, C. et al. (2009) Potential use of Acacia mearnsii condensed tannins to reduce methane emissions and nitrogen excretion from grazing dairy cows. Can. J. Anim. Sci. 89, 241-251.

Grainger, C., Clarke, T., Beauchemin, K. A., McGinn, S. M., \& Eckard, R. J. (2008) Supplementation with whole cottonseed reduces methane emissions and can profitably increase milk production of dairy cows offered a forage and cereal grain diet. Anim. Prod. Sci. 48, 73-76.

Grainger, C., Williams, R., Clarke, T., Wright, A. D., \& Eckard, R. J. Supplementation with whole cottonseed causes long-term reduction of methane emissions from lactating dairy cows offered a forage and cereal grain diet. J. Dairy Sci. 93, 2612-2619 (2010).

Grainger, C., Williams, R., Eckard, R. J., \& Hannah, M. C. A high dose of monensin does not reduce methane emissions of dairy cows offered pasture supplemented with grain. J. Dairy Sci. 93, 5300-5308 (2010). 
Guan, H., Wittenberg, K. M., Ominski, K. H., \& Krause, D. O. Efficacy of ionophores in cattle diets for mitigation of enteric methane. J. Anim. Sci. 84, 1896-1906 (2006).

Gutierrez-Bañuelos, H. et al. Zoonotic bacterial populations, gut fermentation characteristics and methane production in feedlot steers during oral nitroethane treatment and after the feeding of an experimental chlorate product. Anaerobe 13, 21-31 (2007).

Guyader, J. et al. Additive methane-mitigating effect between linseed oil and nitrate fed to cattle. J. Anim. Sci. 93, 3564-3577 (2015).

Guyader, J. et al. Nitrate but not tea saponin feed additives decreased enteric methane emissions in nonlactating cows. J. Anim. Sci. 93, 5367-5377 (2015).

Guyader, J. et al. Tea saponin reduced methanogenesis in vitro but increased methane yield in lactating dairy cows. J. Dairy Sci. 100, 1845-1855 (2017).

Haaland, G. L., Matsushima, J. K., Johnson, D. E., \& Ward, G. M. Nutritive value of protected tallow product fed with hay to beef cattle as assessed by respiration calorimetry. J. Anim. Sci. 52, 391-397 (1981).

Haisan, J. et al. The effects of feeding 3-nitrooxypropanol on methane emissions and productivity of Holstein cows in mid lactation. J. Dairy Sci. 97, 3110-3119 (2014).

Haisan, J. et al. The effects of feeding 3-nitrooxypropanol at two doses on milk production, rumen fermentation, plasma metabolites, nutrient digestibility, and methane emissions in lactating Holstein cows. Anim. Prod. Sci. 5, 282-289 (2017).

Haisan, J. et al. The effects of feeding 3-nitrooxypropanol at two doses on milk production, rumen fermentation, plasma metabolites, nutrient digestibility, and methane emissions in lactating Holstein cows. Anim. Prod. Sci. 57, 282-289 (2017).

Hales, K. E., Brown-Brandl, T. M., \& Freetly, H. C. Effects of decreased dietary roughage concentration on energy metabolism and nutrient balance in finishing beef cattle. J. Anim. Sci. 92, 264-271 (2014).

Hales, K. E., Brown-Brandl, T. M., \& Freetly, H. C. Effects of decreased dietary roughage concentration on energy metabolism and nutrient balance in finishing beef cattle. J. Anim. Sci. 92, 264-271 (2014).

Hales, K. E., Cole, N. A., \& MacDonald, J. C.. Effects of corn processing method and dietary inclusion of wet distillers grains with solubles on energy metabolism, carbon-nitrogen balance, and methane emissions of cattle. J. Anim. Sci. 90, 3174-3185 (2012).

Hales, K. E., Cole, N. A., \& MacDonald, J. C. Effects of increasing concentrations of wet distillers grains with solubles in steam-flaked, corn-based diets on energy metabolism, carbon-nitrogen balance, and methane emissions of cattle. J. Anim. Sci. 91, 819-828 (2013).

Hales, K. E. et al. The effects of feeding increasing concentrations of corn oil on energy metabolism and nutrient balance in finishing beef steers. J. Anim. Sci. 95, 939-948 (2017).

Hales, K. E., Foote, A. P., Brown-Brandl, T. M., \& Freetly, H. C. Effects of dietary glycerin inclusion at 0, 5, 10, and 15 percent of dry matter on energy metabolism and nutrient balance in finishing beef steers. J. Anim. Sci. 93, 348-356 (2015).

Hammond, K. J. et al. Effects of feeding fresh white clover (Trifolium repens) or perennial ryegrass (Lolium perenne) on enteric methane emissions from sheep. Anim. Feed Sci. Technol. 166, 398-404 (2011).

Hammond, K. J. et al. The effects of fresh forages and feed intake level on digesta kinetics and enteric methane emissions from sheep. Anim. Feed Sci. Technol. 193, 32-43 (2014).

Hammond, K. J. et al. The inclusion of forage mixtures in the diet of growing dairy heifers: Impacts on digestion, energy utilisation, and methane emissions. Agric. Ecosyst. Environ.197, 88-95 (2014).

Hammond, K. J., Humphries, D. J., Crompton, L. A., Kirton, P., \& Reynolds, C. K.. Effects of forage source and extruded linseed supplementation on methane emissions from growing dairy cattle of differing body weights. J. Dairy Sci. 98, 8066-8077 (2015). 
Haque, N., Toppo, S., Saraswat, M. L., \& Khan, M. Y. Effect of feeding Leucaena leucocephala leaves and twigs on energy utilization by goats. Anim. Feed Sci. Technol., 142, 330-338 (2008).

Hart, K. J., Martin, P. G., Foley, P. A., Kenny, D. A., \& Boland, T. M.Effect of sward dry matter digestibility on methane production, ruminal fermentation, and microbial populations of zero-grazed beef cattle. J. Anim. Sci. 87, 3342-3350 (2009).

Hart, K., G Martin, P., A Foley, P., Kenny, D., \& Boland, T. Effect of sward dry matter digestibility on methane production, ruminal fermentation, and microbial populations of zero-grazed beef cattle. J. Anim. Sci. 87, 3342-3350 (2009).

Hatew, B. et al. Effects of dietary starch content and rate of fermentation on methane production in lactating dairy cows. J. Dairy Sci. 98, 486-499 (2015).

Hatew, B., Bannink, A., van Laar, H., de Jonge, L. H., \& Dijkstra, J. Increasing harvest maturity of wholeplant corn silage reduces methane emission of lactating dairy cows. J. Dairy Sci. 99, 354-368 (2016).

Hegarty, R. S., Bird, S. H., Vanselow, B. A., \& Woodgate, R. Effects of the absence of protozoa from birth or from weaning on the growth and methane production of lambs. Br. J. Nutr. 100, 1220-1227 (2008).

Hegarty, R. S., Goopy, J. P., Herd, R. M., \& McCorkell, B. Cattle selected for lower residual feed intake have reduced daily methane production. J. Anim. Sci.85, 1479-1486 (2007).

Hellwing, A. L. F., Sørensen, M. T., Weisbjerg, M. R., Vestergaard, M., \& Lund, P. Can rapeseed lower methane emission from heifers?. Acta Agric. Scand., Sec. A - Anim. Sci. 62, 259-262 (2012).

Hemphill, C. N. et al. Effects of feeding monensin to bred heifers fed in a drylot on nutrient and energy balance. J. Anim. Sci. 96, 1171-1180 (2018).

Henry, D. et al. Effects of chitosan on nutrient digestibility, methane emissions, and in vitro fermentation in beef cattle. J. Anim. Sci. 93, 3539-3550 (2015).

Hess, H. D. et al. Ruminal fermentation, methanogenesis and nitrogen utilization of sheep receiving tropical grass hay-concentrate diets offered with Sapindus saponaria fruits and Cratylia argentea foliage. Anim. Sci. 79, 177-189 (2004).

Hindrichsen, I. K., Wettstein, H. R., Machmüller, A., \& Kreuzer, M. Methane emission, nutrient degradation and nitrogen turnover in dairy cows and their slurry at different milk production scenarios with and without concentrate supplementation. Agric. Ecosyst. Environ. 113, 150-161 (2006).

Hindrichsen, I. K., Wettstein, H. R., Machmüller, A., Jörg, B., \& Kreuzer, M. Effect of the carbohydrate composition of feed concentratates on methane emission from dairy cows and their slurry. Environ. Monit. Assess. 107, 329-350 (2005).

Hironaka, R., Mathison, G. W., Kerrigan, B. K., \& Vlach, I. The effect of pelleting of alfalfa hay on methane production and digestibility by steers. Sci. Total Environ. 180, 221-227 (1996).

Hofmeyr, H. S. et al. The replacement of maize meal with sodium hydroxide treated wheat straw in growth diets for lambs. S. Afr. J. Anim. Sci. 12, 113-118 (1982).

Hollmann, M. et al. Enteric methane emissions and lactational performance of Holstein cows fed different concentrations of coconut oil. J. Dairy Sci. 95, 2602-2615 (2012).

Hollmann, M., Powers, W. J., Fogiel, A. C., Liesman, J. S., \& Beede, D. K. Response profiles of enteric methane emissions and lactational performance during habituation to dietary coconut oil in dairy cows. $J$. Dairy Sci. 96, 1769-1781 (2013).

Holmes, C. W., Hughes, T. P., \& Christensen, R. Energy metabolism of Brahman $\times$ Friesian and Friesian calves, and the influence of an increase in rectal temperature on their heat production. New Zeal. J. Agric. Res. 21, 557-561 (1978).

Holter J. B., et al. Urea for lactating dairy cattle. V. Concentrate fiber and urea in a corn silage-high concentrate ration. J. Dairy Sci. 54, 1475-1481 (1971).

Holter, J. B., Kim, C. W., \& Colovos, N. F. Methionine Hydroxy Analog for Lactating Dairy Cows. J. Dairy Sci. 55, 460-465 (1972). 
Holtshausen, L. et al. (2009). Feeding saponin-containing Yucca schidigera and Quillaja saponaria to decrease enteric methane production in dairy cows. J. Dairy Sci. 92, 2809-2821.

Hosoda, K., Nishida, T., Park, W. Y., \& Eruden, B. Influence of Menthaxpiperita L.(peppermint) supplementation on nutrient digestibility and energy metabolism in lactating dairy cows. Asian-Australas. J. Anim. Sci. 18, 1721-1726 (2005).

Hossain, S. A. et al. Feed conversion efficiency, milk production and methane emission in cows fed balanced rations containing bypass protein feed. Indian J. Anim. Nutr. 34, 374-381 (2017).

Houdijk, J. G. M. et al.. Animal health and greenhouse gas intensity: the paradox of periparturient parasitism. Int. J. Parasitol. 47, 633-64 (2017).

Hristov, A. N. et al. Effect of Saccharomyces cerevisiae fermentation product on ruminal fermentation and nutrient utilization in dairy cows. J. Dairy Sci.93, 682-692 (2010).

Hristov, A. N. et al. Effect of Origanum vulgare L. leaves on rumen fermentation, production, and milk fatty acid composition in lactating dairy cows. J. Dairy Sci. 9, 1189-1202 (2013).

Hristov, A. N. et al. An inhibitor persistently decreased enteric methane emission from dairy cows with no negative effect on milk production. PNAS 112, 10663-10668 (2015).

Hulshof, R. B. et al. Dietary nitrate supplementation reduces methane emission in beef cattle fed sugarcanebased diets. J. Anim. Sci. 90, 2317-2323 (2012).

Hünerberg, M. et al. Effect of dried distillers grains plus solubles on enteric methane emissions and nitrogen excretion from growing beef cattle. J. Anim. Sci. 91, 2846-2857 (2013).

Hünerberg, M. et al. Effect of dried distillers' grains with solubles on enteric methane emissions and nitrogen excretion from finishing beef cattle. Can. J. Anim. Sci. 93, 373-385 (2013).

Huyen, M. et al. Inclusion of sainfoin (Onobrychis viciifolia) silage in dairy cow rations affects nutrient digestibility, nitrogen utilization, energy balance, and methane emissions. J. Dairy Sci. 99, 3566-3577 (2016).

Ibáñez, C. et al. Murciano-granadina goat performance and Methane emission after replacing barley grain with fibrous by-products. PLoS One 11, 3 (2016).

Islam, M., Abe, H., Hayashi, Y., \& Terada, F. Effects of feeding Italian ryegrass with corn on rumen environment, nutrient digestibility, methane emission, and energy and nitrogen utilization at two intake levels by goats. Small Rumin. Res. 38, 165-174 (2000).

Islam, M., Abe, H., Terada, F., Iwasaki, K., \& Tano, R. Effects of levels of feed intake and inclusion of corn on rumen environment, nutrient digestibility, methane emission and energy and protein utilization by goats fed alfalfa pellets. Asian-Australas. J. Anim. Sci. 13, 948-956 (2000).

Itabashi, H., Kobayashi, T., \& Matsumoto, M. The effects of rumen ciliate protozoa on energy metabolism and some constituents in rumen fluid and blood plasma of goats. Jpn. J. Zootec. Sci. 55, 248-246 (1984).

Faichney, G. J., Graham, N. M., \& Walker, D. M. Rumen characteristics, methane emissions, and digestion in weaned lambs reared in isolation. Aust. J. Agric. Res. 50, 1083-1089 (1999).

Jennings, J. S. et al. Energy costs of feeding excess protein from corn-based by-products to finishing cattle. $J$. Anim. Sci. 96, 653-669 (2018).

Jiao H. P. et al. Effect of concentrate feed level on methane emissions from grazing dairy cows. J. Dairy Sci. 97, 7043-7053 (2014).

Johnson, K. A. et al. The effect of oilseeds in diets of lactating cows on milk production and methane emissions. J. Dairy Sci. 85, 1509-1515 (2002).

Johnson, D. E. Adaptational responses in nitrogen and energy balance of lambs fed a methane inhibitor. $J$. Anim. Sci. 38, 154-157 (1974).

Jonker, A. et al. Feeding diets with fodder beet decreased methane emissions from dry and lactating dairy cows in grazing systems. Anim. Prod. Sci. 57, 1445-1450 (2017).

Jonker, A. et al. Sheep from low-methane-yield selection lines created on alfalfa pellets also have lower methane yield under pastoral farming conditions. J. Anim. Sci. 95, 3905-3913 (2017). 
Jonker, A., Molano, G., Antwi, C., \& Waghorn, G. Feeding lucerne silage to beef cattle at three allowances and four feeding frequencies affects circadian patterns of methane emissions, but not emissions per unit of intake. Anim. Prod. Sci. 54, 1350-1353 (2014).

Jordan, E. et al. Effect of refined coconut oil or copra meal on methane output and on intake and performance of beef heifers. J. Anim. Sci. 84, 162-170 (2006).

Jordan, E. et al. Effect of refined soy oil or whole soybeans on intake, methane output, and performance of young bulls. J. Anim. Sci. 84, 2418-2425 (2006).

Jordan, E., Lovett, D. K., Hawkins, M., Callan, J. J., \& O'Mara, F. P. The effect of varying levels of coconut oil on intake, digestibility and methane output from continental cross beef heifers. Anim. Sci. 82, 859-865 (2006).

Joyner, A. E., Jr., Brown, L. J., Fogg, T. J., \& Rossi, R. T.. Effect of Monensin on Growth, Feed Efficiency and Energy Metabolism of Lambs. J. Anim. Sci. 48, 1065-1069 (1979).

Judy, J. V. et al. Energy balance and diurnal variation in methane production as affected by feeding frequency in Jersey cows in late lactation. J. Dairy Sci. 101, 10899-10910 (2018).

Karlsson, J. et al. in Proceedings of the 8th Nordic Feed Science Conference (eds Uden, P. et al.), 42-47 (Swedish University of Agricultural Sciences, Uppsala, 2017).

Kawashima, T., Sumamal, W., Pholsen, P., Chaithiang, R., \& Terada, F. Comparative study on energy and nitrogen metabolism of Brahman cattle and sheep given ruzi grass hay with different levels of soybean meal. Jpn. Agric. Res. Q. 41, 253-260 (2007).

Kempton, T. J., \& Leng, R. A. Protein nutrition of growing lambs. 1. Responses in growth and rumen function to supplementation of a low-protein-cellulosic diet with either urea, casein or formaldehyde-treated casein. Br. J. Nutr. 42, 289-302 (1979).

Kennedy, P. M., \& Milligan, L. P. Effects of cold exposure on digestion, microbial synthesis and nitrogen transformations in sheep. Br. J. Nutr. 39, 105-117 (1978).

Kidane, A. et al. Interaction between feed use efficiency and level of dietary crude protein on enteric methane emission and apparent nitrogen use efficiency with Norwegian Red dairy cows. J. Anim. Sci. 96, 3967-3982 (2018).

Kim, S. H. et al. Effects of reductive acetogenic bacteria and lauric acid on in vivo ruminal fermentation, microbial populations, and methane mitigation in Hanwoo steers in South Korea. J. Anim. Sci. 96, 4360-4367 (2018).

Kirkpatrick, D. E. S., R. W. The effect of method of conservation of grass and supplementation on energy and nitrogen utilization by lambs. J. Agric. Sci. 133, 409-417 (1999).

Klevenhusen, F., Duval, S., Zeitz, J. O., Kreuzer, M., \& Soliva, C. R. Diallyl disulphide and lovastatin: effects on energy and protein utilisation in, as well as methane emission from, sheep. Arch. Anim. Nutr. 65, 255-266 (2011).

Klevenhusen, F., Zeitz, J. O., Duval, S., Kreuzer, M., \& Soliva, C. R. Garlic oil and its principal component diallyl disulfide fail to mitigate methane, but improve digestibility in sheep. Anim. Feed Sci. Technol. 166, 356-363 (2011).

Klop, G., Hatew, B., Bannink, A., \& Dijkstra, J. Feeding nitrate and docosahexaenoic acid affects enteric methane production and milk fatty acid composition in lactating dairy cows. J. Dairy Sci. 99,1161-1172 (2015).

Kolling, G. J. et al. Performance and methane emissions in dairy cows fed oregano and green tea extracts as feed additives. J. Dairy Sci. 101, 4221-4234 (2018).

Kolver, E. S. Supplemental fumarate did not influence milksolids or methane production from dairy cows fed high quality pasture. Proc. NZ. Grassl. Assoc. 66, 409-415 (2006).

Lee, C., Araujo, R. C., Koenig, K. M., \& Beauchemin, K. A. Effects of encapsulated nitrate on enteric methane production and nitrogen and energy utilization in beef heifers. J. Anim. Sci. 93, 2391-2404 (2015). 
Lee, C. et al. Effects of encapsulated nitrate on growth performance, carcass characteristics, nitrate residues in tissues, and enteric methane emissions in beef steers: finishing phase. J. Anim. Sci. 95, 3712-3726 (2017).

Lee, J. M., Woodward, S. L., Waghorn, G. C., \& Clark, D. A. Methane emissions by dairy cows fed increasing proportions of white clover (Trifolium repens) in pasture. Proc. NZ. Grassl. Assoc. 66, 151-155 (2004).

Li, L., Davis, J., Nolan, J., \& Hegarty, R. An initial investigation on rumen fermentation pattern and methane emission of sheep offered diets containing urea or nitrate as the nitrogen source. Anim. Prod. Sci. 52, 653-658 (2012).

Li, L., I. Silveira, C., Nolan, J., R. Godwin, I., Leng, R., \& Hegarty, R.. Effect of added dietary nitrate and elemental sulfur on wool growth and methane emission of Merino lambs. Anim. Prod. Sci. 53, 1195-1201 (2013).

Li, X. et al. Asparagopsis taxiformis decreases enteric methane production from sheep. Anim. Prod. Sci. 58, 681-688 (2018).

$\mathrm{Li}, \mathrm{X}$. et al. Effects of mineral salt supplement on enteric methane emissions, ruminal fermentation and methanogen community of lactating cows. Anim. Sci. J. 88, 1049-1057 (2017).

Li, Z. J. et al. Dynamics of methanogenesis, ruminal fermentation, and alfalfa degradation during adaptation to monensin supplementation in goats. J. Dairy Sci. 101, 1048-1059 (2018).

$\mathrm{Li}, \mathrm{Z}$. J. et al. Effects of fumaric acid supplementation on methane production and rumen fermentation in goats fed diets varying in forage and concentrate particle size. J. Anim. Sci. Biotechnol. 9, 21 (2018).

Lila, Z. A. et al. Effect of cyclodextrin diallyl maleate on methane production, ruminal fermentation and microbes in vitro and in vivo. Anim. Sci. J. 75, 15-22 (2004).

Lila, Z. A., Mohammed, N., Kanda, S., Kurihara, M., \& Itabashi, H. Sarsaponin effects on ruminal fermentation and microbes, methane production, digestibility and blood metabolites in steers. AsianAustralas. J. Anim. Sci. 18, 1746 (2005).

Lima, P. D. et al. Methane emission of Santa Inês sheep fed cottonseed by-products containing different levels of gossypol. Trop. Anim. Health Prod 46, 285-288 (2014).

Liu, C. et al. in 2012 IX International Livestock Environment Symposium(eds. Cambra-Lopez, M., Wheeler, E. F., Moura, D. J., Janni, K. \& Gates, R. S.), ILES12-0599 (American Society of Agricultural and Biological Engineers, Valencia, 2012).

Liu, C. et al. Long-term effects of ensiled cornstalk diet on methane emission, rumen fermentation, methanogenesis and weight gain in sheep. Small Rumin. Res. 115, 15-20 (2013).

Liu, C. et al. Effects of isovalerate supplementation on microbial status and rumen enzyme profile in steers fed on corn stover based diet. Livest. Sci. 161, 60-68 (2014).

Liu, H. W. et al. Effects of Suaeda glauca crushed seed on rumen microbial populations, ruminal fermentation, methane emission, and growth performance in Ujumqin lambs. Anim. Feed Sci. Technol. 210 , 104-113 (2015).

Liu, H. W. et al. Effects of Lespedeza Condensed Tannins Alone or with Monensin, Soybean Oil, and Coconut Oil on Feed Intake, Growth, Digestion, Ruminal Methane Emission, and Heat Energy by Yearling Alpine Doelings. J. Anim. Sci. 96, 473-473 (2018).

Liu, H., Vaddella, V., \& Zhou, D. Effects of chestnut tannins and coconut oil on growth performance, methane emission, ruminal fermentation, and microbial populations in sheep. J. Dairy Sci. 94, 6069-6077 (2011).

Livingstone, K. M. et al. Effects of forage type and extruded linseed supplementation on methane production and milk fatty acid composition of lactating dairy cows. J. Dairy Sci. 98, 4000-4011 (2015).

Lopes, J. C. et al. Effect of 3-nitrooxipropanol on methane and hydrogen emissions, methane isotopic signature, and ruminal fermentation in dairy cows. J. Dairy Sci. 99, 5335-5344 (2016). 
López, M. C., \& Fernández, C. Energy partitioning and substrate oxidation by Murciano-Granadina goats during mid lactation fed soy hulls and corn gluten feed blend as a replacement for corn grain. J. Dairy Sci. 96, 4542-4552 (2013).

López, M. C., \& Fernández, C. Changes in heat production by sheep of Guirra breed after increase in quantity of barley grain on the diet. Small Rumin. Res. 109, 113-118 (2013).

López, M. C., Estellés, F., Moya, V. J., \& Fernández, C. Use of dry citrus pulp or soybean hulls as a replacement for corn grain in energy and nitrogen partitioning, methane emissions, and milk performance in lactating Murciano-Granadina goats. J. Dairy Sci. 97, 7821-7832 (2014).

Lovett, D. et al. Effect of forage/concentrate ratio and dietary coconut oil level on methane output and performance of finishing beef heifers. Livest. Prod. Sci. 84, 135-146 (2003).

Lovett, D. et al. Manipulating enteric methane emissions and animal performance of late-lactation dairy cows through concentrate supplementation at pasture. J. Dairy Sci. 88, 2836-2842 (2005).

Loza, C. et al. Energy expenditure and methane emissions of grazing dairy cows at two levels of pre-grazing herbage biomass. Grassl. Sci. Eur. 23, 622-624

Lund, P. et al. The acute effect of addition of nitrate on in vitro and in vivo methane emission in dairy cows. Anim. Prod. Sci. 54, 1432-1435 (2014).

Ma, T. et al. Effect of supplementation of allicin on methanogenesis and ruminal microbial flora in Dorper crossbred ewes. J. Anim. Sci. Biotechnol. 7, 1 (2016).

Ma, T. et al. Dietary supplementation with mulberry leaf flavonoids inhibits methanogenesis in sheep. Anim. Sci. J. 88, 72-78 (2017).

Machmüller, A., \& Kreuzer, M. Methane suppression by coconut oil and associated effects on nutrient and energy balance in sheep. Can. J. Anim. Sci. 79, 65-72 (1999).

Machmüller, A., Ossowski, D. A., \& Kreuzer, M. Comparative evaluation of the effects of coconut oil, oilseeds and crystalline fat on methane release, digestion and energy balance in lambs. Anim. Feed Sci.

Technol. 85, 41-60 (2000).

Machmüller, A., Soliva, C. R., \& Kreuzer, M. Effect of coconut oil and defaunation treatment on methanogenesis in sheep. Reprod. Nutr. Dev. 43, 41-55 (2003).

Machmüller, A., Soliva, C. R., \& Kreuzer, M. Methane-suppressing effect of myristic acid in sheep as affected by dietary calcium and forage proportion. Br. J. Nutr. 90, 529-540 (2003).

Malik, P. K. et al. Effect of tamarind seed husk supplementation on ruminal methanogenesis, methanogen diversity and fermentation characteristics. Carbon Manage. 8, 319-329 (2017).

Malik, P. K. et al.Enteric methane mitigation in sheep through leaves of selected tanniniferous tropical tree species. Livest. Sci. 200, 29-34 (2017).

Marett, L. C. et al. Partitioning of energy and nitrogen in lactating primiparous and multiparous HolsteinFriesian cows with divergent residual feed intake. Anim. Prod. Sci. 57, 1499-1506 (2017).

Margan, D. E. Energy and protein value of combinations of maize silage and red clover hay for ruminants, using adult sheep as a model. Anim. Prod. Sci. 34, 319-329 (1994).

Martin, C. et al. Methane output and rumen microbiota in dairy cows in response to long-term supplementation with linseed or rapeseed of grass silage-or pasture-based diets. Proc. NZ Soc. Anim.

Prod. 71, 243-247 (2011).

Martin, C. et al. Increasing linseed supply in dairy cow diets based on hay or corn silage: Effect on enteric methane emission, rumen microbial fermentation, and digestion. J. Dairy Sci. 99, 3445-3456 (2016).

Martin, C., Rouel, J., Jouany, J. P., Doreau, M., \& Chilliard, Y. Methane output and diet digestibility in response to feeding dairy cows crude linseed, extruded linseed, or linseed oil. J. Anim. Sci. 86, 2642-2650 (2008).

Martínez-Fernández, G. et al. Effects of ethyl-3-nitrooxy propionate and 3-nitrooxypropanol on ruminal fermentation, microbial abundance, and methane emissions in sheep. J. Dairy Sci. 97, 3790-3799 (2014). 
Martínez-Fernández, G. et al. Effects of propyl propane thiosulfinate on nutrient utilization, ruminal fermentation, microbial population and methane emissions in goats. Anim. Feed Sci. Technol. 191: 16-25 (2014).

Martinez-Fernandez, G. et al. 3-NOP vs. halogenated compound: methane production, ruminal fermentation and microbial community response in forage fed cattle. Front. Microbiol. 9, 1582 (2018).

Mathison. G. W. et al. Rate of starch degradation, apparent digestibility and rate and efficiency of steer gain as influenced by barley grain volume-weight and processing method. Can. J. Anim. Sci. 71, 867-878 (1991). Mc Geough, E. J. et al. Methane emissions, feed intake, and performance of finishing beef cattle offered maize silages harvested at 4 different stages of maturity. J. Anim. Sci. 88, 1479-1491 (2010).

Mc Geough, E. J. et al. Methane emissions, feed intake, performance, digestibility, and rumen fermentation of finishing beef cattle offered whole-crop wheat silages differing in grain content. J. Anim. Sci. 88, 27032716 (2010).

McCaughey, W. P., Wittenberg, K., \& Corrigan, D. Methane production by steers on pasture. Can. J. Anim. Sci. 77, 519-524 (1997).

McCaughey, W. P., Wittenberg, K., \& Corrigan, D. Impact of pasture type on methane production by lactating beef cows. Can. J. Anim. Sci. 79, 221-226 (1999).

McDonnell, R . P. et al. Effect of divergence in phenotypic residual feed intake on methane emissions, ruminal fermentation, and apparent whole-tract digestibility of beef heifers across three contrasting diets. $J$. Anim. Sci. 94, 1179-1193 (2016).

McGinn, S. M., Beauchemin, K. A., Coates, T., \& Colombatto, D. Methane emissions from beef cattle: Effects of monensin, sunflower oil, enzymes, yeast, and fumaric acid. J. Anim. Sci. 82, 3346-3356 (2004).

McGinn, S. M., Chung, Y. H., Beauchemin, K. A., Iwaasa, A. D., \& Grainger, C. Use of corn distillers' dried grains to reduce enteric methane loss from beef cattle. Can. J. Anim. Sci. 89, 409-413 (2009).

Mehra, U. R. et al. Effect of Sources of Supplementary Protein on Intake, Digestion and Efficiency of Energy Utilization in Buffaloes Fed Wheat Straw Based Diets. Asian-Australas. J. Anim. Sci. 19, 638-644 (2006).

Melchior, E. A. et al. The effects of feeding monensin on rumen microbial communities and methanogenesis in bred heifers fed in a drylot. Livest. Sci. 212, 131-136 (2018).

Miri, V. H., Tyagi, A. K., Ebrahimi, S. H., \& Mohini, M. Effect of cumin (Cuminum cyminum) seed extract on milk fatty acid profile and methane emission in lactating goat. Small Rumin. Res. 113, 66-72 (2013).

Mitsumori, M. et al. Responses in digestion, rumen fermentation and microbial populations to inhibition of methane formation by a halogenated methane analogue. Br. J. Nutr. 108, 482-491 (2012).

Mitsumori, M. et al. Effect of cashew nut shell liquid on metabolic hydrogen flow on bovine rumen fermentation. Anim. Sci. J. 85, 227-232 (2014).

Moate, P. J. et al. Influence of cold-pressed canola, brewers grains and hominy meal as dietary supplements suitable for reducing enteric methane emissions from lactating dairy cows. Anim. Feed Sci. Technol. 166, 254-264 (2011).

Moate, P. J. et al. Effects of feeding algal meal high in docosahexaenoic acid on feed intake, milk production, and methane emissions in dairy cows. J. Dairy Sci. 96, 3177-3188 (2013).

Moate, P. J. et al. Wheat is more potent than corn or barley for dietary mitigation of enteric methane emissions from dairy cows. J. Dairy Sci. 100, 7139-7153 (2017).

Moate, R. J. et al. Wheat is more potent than corn or barley for dietary mitigation of enteric methane emissions from dairy cows. J. Dairy Sci 100, 7139-7153 (2017)

Moe, P. W., Tyell, H. F., \& Hooven, N. W. Physical form and energy value of corn grain. J. Dairy Sci. 56, 1298-1304 (1973).

Mohammed, N. et al. Effect of Japanese horseradish oil on methane production and ruminal fermentation in vitro and in steers. J. Anim. Sci. 82, 1839-1846 (2004). 
Mohammed, N. et al. Effects of cyclodextrin-iodopropane complex on methane production, ruminal fermentation and microbes, digestibility and blood metabolites in steers. Anim. Sci. J. 75, 131-137 (2004). Molano, G., \& Clark, H. The effect of level of intake and forage quality on methane production by sheep. Aust. J. Exp. Agric. 48, 219-222 (2008).

Molano, G., Knight, T. W., \& Clark, H. Fumaric acid supplements have no effect on methane emissions per unit of feed intake in wether lambs. Anim. Prod. Sci. 48, 165-168 (2008).

Moreira, G. et al. Tropical tanniniferous legumes used as an option to mitigate sheep enteric methane emission. Trop. Anim. Health Prod. 45, 879-882 (2013).

Morgavi, D. P., Jouany, J. P., \& Martin, C. Changes in methane emission and rumen fermentation parameters induced by refaunation in sheep. Anim. Prod. Sci. 48, 69-72 (2008).

Morgavi, D. P., Martin, C., Jouany, J. P., \& Ranilla, M. J. Rumen protozoa and methanogenesis: not a simple cause-effect relationship. Br. J. Nutr. 107, 388-397 (2012).

Moscoso, J. E. et al.. Methane production in grazing cattle supplemented with silage, concentrate and tannins in the Peruvian highlands during the dry season. Rev. de Investig. Vet. del Peru 28, 822-833 (2017).

Mosoni, P., Martin, C., Forano, E., \& Morgavi, D. P. Long-term defaunation increases the abundance of cellulolytic ruminococci and methanogens but does not affect the bacterial and methanogen diversity in the rumen of sheep. J. Anim. Sci. 89, 783-791 (2011).

Moss, A. R., \& Givens, D. I. The effect of supplementing grass silage with soya bean meal on digestibility, in sacco degradability, rumen fermentation and methane production in sheep. Anim. Feed Sci. Technol. 97, 127143 (2002).

Moss, A. R., Givens, D. I., \& Garnsworthy, P. C. The effect of alkali treatment of cereal straws on digestibility and methane production by sheep. Anim. Feed Sci. Technol. 49, 245-259 (1994).

Munoz, C. et al. Effects of dietary concentrate supplementation on enteric methane emissions and performance of late lactation dairy cows. Chil. J. Agric. Res. 78, 429-437 (2018).

Muñoz, C., Hube, S., Morales, J. M., Yan, T., \& Ungerfeld, E. M. Effects of concentrate supplementation on enteric methane emissions and milk production of grazing dairy cows. Livest. Sci. 175, 37-46 (2015).

Munoz, C., Wills, D. A., \& Yan, T. Effects of dietary active dried yeast (Saccharomyces cerevisiae) supply at two levels of concentrate on energy and nitrogen utilisation and methane emissions of lactating dairy cows.

Anim. Prod. Sci. 57, 656-664 (2016).

Murray, P., Gill, E., Gilhespy, S. L., \& Jarvis, S. C. A comparison of methane emissions from sheep grazing pastures with differing management intensities. Nutr. Cycling Agroecosyst. 60, 93-97 (2001).

Mwenya, B. et al. Effects of including $\beta 1-4$ galacto-oligosaccharides, lactic acid bacteria or yeast culture on methanogenesis as well as energy and nitrogen metabolism in sheep. Anim. Feed Sci. Technol. 115, 313-326 (2004).

Mwenya, B. et al. Effects of probiotic-vitacogen and beta 1-4 galacto-oligosaccharides supplementation on methanogenesis and energy and nitrogen utilization in dairy cows. Asian-Australas. J. Anim. Sci. 17, 349-354 (2004).

Mwenya, B. et al. Comparing the effects of $\beta 1-4$ galacto-oligosaccharides and L-cysteine to monensin on energy and nitrogen utilization in steers fed a very high concentrate diet. Anim. Feed Sci. Technol. 118, 19-30 (2005).

Na, R., Dong, H., Zhu, Z., Chen, Y., \& Xin, H. Effects of forage type and dietary concentrate to forage ratio on methane emissions and rumen fermentation characteristics of dairy cows in China. ASABE 56, 1115-1122 (2013).

$\mathrm{Na}$, Y. et al. Effects of dietary forage-to-concentrate ratio on nutrient digestibility and enteric methane production in growing goats (Capra hircus hircus) and Sika deer (Cervus nippon hortulorum). AsianAustralas. J. Anim. Sci. 30, 967-972 (2017). 
$\mathrm{Na}$, Y. et al. Effects of feeding level on nutrient digestibility and enteric methane production in growing goats (Capra hircus hircus) and Sika deer (Cervus nippon hortulorum). Asian-Australas. J. Anim. Sci. 31, 12381243 (2018).

Nampoothiri, V. M. et al. Growth performance, and enteric and manure greenhouse gas emissions from Murrah calves fed diets with different forage to concentrate ratios. Anim. Nutr. 4, 215-221 (2018).

Nelson, M. L., Westberg, H. H., \& Parish, S. M. Effects of tallow on the energy metabolism of wethers fed barley finishing diets. J. Anim. Sci. 79, 1892-1904 (2001).

Neto, G. B. et al. Effect of starch-based supplementation level combined with oil on intake, performance, and methane emissions of growing Nellore bulls on pasture. J. Anim. Sci. 93, 2275-2284 (2015).

Neto, G. B., Berndt, A., Nogueira, J. R., Demarchi, J. J. A. A., \& Nogueira, J. C. Monensin and protein supplements on methane production. S. Afr. J. Anim. Sci. 39, 280-283 (2009).

Newbold, J. R. et al. The effect of incremental levels of dietary nitrate on methane emissions in Holstein steers and performance in Nelore bulls. J. Anim. Sci. 92, 5032-5040 (2014).

Nguyen, S. H. and R. S. Hegarty. Effects of defaunation and dietary coconut oil distillate on fermentation, digesta kinetics and methane production of Brahman heifers. J. Anim. Physio. Anim. Nutr. 101, 984-993 (2017).

Nguyen, S. H. et al.. Methane emissions and productivity of defaunated and refaunated sheep while grazing. Small Rumin. Res. 161, 28-33 (2018).

Nguyen, S., Barnett, M., \& Hegarty, R. Use of dietary nitrate to increase productivity and reduce methane production of defaunated and faunated lambs consuming protein deficient chaff. Anim. Prod. Sci. 56, 290-297 (2015).

Nishida, T. et al. Digestibility, methane production and chewing activity of steers fed whole-crop round bale corn silage preserved at three maturities. Anim. Feed Sci. Technol. 135, 42-51 (2007).

Nishida, T., Kurihara, M., Purnomoadi, A., Terada, F., \& Shibata, M. Methane suppression by calcium soaps of stearic, oleic and linoleic acid mixtures in cattle. In Proceedings of the 14th Symposium on Energy

Metabolism of Farm Animal (eds McCracken, K. Unsworth, E. F., \& Wylie, A. R. G), 379-382 (Department of Agriculture for Northern Ireland and The Queen's University of Belfast, Belfast, 1997).

Niu, M., Appuhamy, J., Leytem, A., Dungan, R., \& Kebreab, E. Effect of dietary crude protein and forage contents on enteric methane emissions and nitrogen excretion from dairy cows simultaneously. Anim. Prod. Sci. 56, 312-321 (2015).

Nkrumah, J. D. et al. Relationships of feedlot feed efficiency, performance, and feeding behavior with metabolic rate, methane production, and energy partitioning in beef cattle. J. Anim. Sci. 84, 145-153 (2006).

Nolan, J. V., Hegarty, R. S., Hegarty, J., Godwin, I. R., \& Woodgate, R. Effects of dietary nitrate on fermentation, methane production and digesta kinetics in sheep. Anim. Prod. Sci. 50, 801-806 (2010). O’Neill, B. F. et al. Effects of a perennial ryegrass diet or total mixed ration diet offered to spring-calving Holstein-Friesian dairy cows on methane emissions, dry matter intake, and milk production. J. Dairy Sci. 94, 1941-1951 (2011).

Oddy, V., Ewoldt, C., Jones, A., \& Warren, H. Metabolisable energy content of diets based on oats grain. Aust. J. Exp. Agric. 30, 503-506 (1990).

Odongo, N. E. et al. Long-term effects of feeding monensin on methane production in lactating dairy cows. $J$. Dairy Sci. 90, 1781-1788 (2007).

O'Kelly, J. C., \& Spiers, W. G. Effect of monensin on methane and heat productions of steers fed lucerne hay either ad libitum or at the rate of $250 \mathrm{~g}$ /hour. Crop Pasture Sci. 43, 1789-1793 (1992).

Olijhoek, D. W. et al. Effect of dietary nitrate level on enteric methane production, hydrogen emission, rumen fermentation, and nutrient digestibility in dairy cows. J. Dairy Sci. 99, 6191-6205 (2016). 
Olijhoek, D. W. et al. Methane production, rumen fermentation, and diet digestibility of Holstein and Jersey dairy cows being divergent in residual feed intake and fed at 2 forage-to-concentrate ratios. J. Dairy Sci. 101, 9926-9940 (2018).

Oliveira, L. F. et al. Feed efficiency and enteric methane production of Nellore cattle in the feedlot and on pasture. Anim. Prod. Sci. 58, 886-893 (2018).

Ominski, K. H., Boadi, D. A., \& Wittenberg, K. M. Enteric methane emissions from backgrounded cattle consuming all-forage diets. Can. J. Anim. Sci. 86, 393-400 (2006).

Osakwe, I. I., \& Drochner, W. Nutritive value of Morinda lucida and its fermentation parameters in West African dwarf (WAD) sheep when fed as supplement to grass hay. Small Rumin. Res. 64, 107-115 (2006).

Osakwe, I. I., Steingass, H., \& Drochner, W. Effect of dried Elaeis guineense supplementation on nitrogen and energy partitioning of WAD sheep fed a basal hay diet. Anim. Feed Sci. Technol. 117, 75-83 (2004).

Panthee, A. et al. Effect of feeding garlic leaves on rumen fermentation, methane emission, plasma glucose kinetics, and nitrogen utilization in sheep. J. Anim. Sci. Technol. 59,14 (2017).

Pathak, A. K. et al. Effect of condensed tannins from Ficus infectoria and Psidium guajava leaf meal mixture on nutrient metabolism, methane emission and performance of lambs. Asian-Australas. J. Anim. Sci. 30, 1702-1710 (2017).

Patil, A. K. et al. Effect of feeding compressed complete feed block with or without deoiled mahua seed cake on methane production and energy utilization in crossbred calves. Indian J. Anim. Sci. 87, 1046-1048 (2017).

Patra, A. K., Kamra, D. N., Bhar, R., Kumar, R., \& Agarwal, N. Effect of Terminalia chebula and Allium sativum on in vivo methane emission by sheep. J. Anim. Physiol. Anim. Nutr. 95, 187-191 (2011).

Pattanaik, A. K., Sastry, V. R. B., Katiyar, R. C., \& Lal, M. Influence of grain processing and dietary protein degradability on nitrogen metabolism, energy balance and methane production in young calves. AsianAustralas. J. Anim. Sci. 16, 1443-1450 (2003).

Pen, B. et al. Effect of potato by-products based silage on rumen fermentation, methane production and nitrogen utilization in Holstein steers. Asian-Australas. J. Anim. Sci. 19, 1283-1290 (2006).

Pen, B., Takaura, K., Yamaguchi, S., Asa, R., \& Takahashi, J. Effects of Yucca schidigera and Quillaja saponaria with or without $\beta$ 1-4 galacto-oligosaccharides on ruminal fermentation, methane production and nitrogen utilization in sheep. Anim. Feed Sci. Technol. 138, 75-88 (2007).

Perry, L. A. et al.. Effect of feeding forage characteristic of wet- or dry-season tropical C4 grass in northern Australia, on methane production, intake and rumen outflow rates in Bos indicus steers. Anim. Prod. Sci. 57, 2033-2041 (2017).

Philippeau, C. et al. Effects of bacterial direct-fed microbials on ruminal characteristics, methane emission, and milk fatty acid composition in cows fed high- or low-starch diets. J. Dairy Sci. 100, 2637-2650 (2017).

Pinares-Patiño, C. S. et al. Is rumen retention time implicated in sheep differences in methane emission. Proc. NZ Grassl. Assoc. 71, 219-222 (2011).

Pinares-Patiño, C. S. et al. Feed intake and methane emissions from cattle grazing pasture sprayed with canola oil. Livest. Sci. 184, 7-12 (2016).

Pinares-Patiño, C. S., Baumont, R., \& Martin, C. Methane emissions by Charolais cows grazing a monospecific pasture of timothy at four stages of maturity. Can. J. Anim. Sci. 83, 769-777 (2003).

Pinares-Patiño, C. S., D’hour, P., Jouany, J. P., \& Martin, C. Effects of stocking rate on methane and carbon dioxide emissions from grazing cattle. Agric. Ecosyst. Environ. 121, 30-46 (2007).

Pinares-Patiño, C. S., McEwan, J. C., Dodds, K. G., Cárdenas, E. A., Hegarty, R. S., Koolaard, J. P., \& Clark, H. Repeatability of methane emissions from sheep. Anim. Feed Sci. Technol. 166-167, 210-218 (2011).

Pinares-Patiño, C. S., Ulyatt, M. J., Lassey, K. R., Barry, T. N., \& Holmes, C. W. Persistence of differences between sheep in methane emission under generous grazing conditions. J. Agric. Sci. 140, 227-233 (2003). 
Pineda, G. S. H. et al. Pithecellobium dulce, Tagetes erecta and Cosmos bipinnatus on reducing enteric methane emission by dairy cows. Ciencia Rural 48, 7 (2018).

Piñeiro-Vázquez, A. T. et al. Energy utilization, nitrogen balance and microbial protein supply in cattle fed Pennisetum purpureum and condensed tannins. J. Anim. Physiol. Anim. Nutr. 101, 159-169 (2016).

Pineiro-Vazquez, A. T. et al. Enteric methane emission in sheep fed Pennisetum purpureum and tropical trees containing condensed tannins. Rev. Mex. Cienc. Pecu. 8, 111-119 (2017).

Pineiro-Vazquez, A. T. et al.. Effect of condensed tannins from Leucaena leucocephala on rumen fermentation, methane production and population of rumen protozoa in heifers fed low-quality forage. AsianAustralas. J. Anim. Sci. 31, 1738-1746 (2018).

Piñeiro-Vázquez, A. T. et al. Effects of quebracho tannin extract on intake, digestibility, rumen fermentation, and methane production in crossbred heifers fed low-quality tropical grass. Trop. Anim. Health Prod. 50, 2936, (2018).

Pirondini, M. et al. Effect of dietary starch concentration and fish oil supplementation on milk yield and composition, diet digestibility, and methane emissions in lactating dairy cows. J. Dairy Sci. 98, 357-372 (2015).

Popova, M. et al. Effect of fibre- and starch-rich finishing diets on methanogenic Archaea diversity and activity in the rumen of feedlot bulls. Anim. Feed Sci. Technol. 166, 113-121 (2011).

Possenti, R. A. et al. Efeitos de dietas contendo Leucaena leucocephala e Saccharomyces cerevisiae sobre a fermentação ruminal e a emissão de gás metano em bovinos. R. B. Zootec. 37, 1509-1516 (2008).

Puchala, R. et al. Effects of different fresh-cut forages and their hays on feed intake, digestibility, heat production, and ruminal methane emission by Boer $\times$ Spanish goats. J. Anim. Sci. 90, 2754-2762 (2012).

Puchala, R. et al. Methane emissions by goats consuming Sericea lespedeza at different feeding frequencies. Anim. Feed Sci. Technol. 175, 76-84 (2012).

Rajaraman, B. et al. Effects of caprylic acid and beta-cyclodextrin complexes on digestibility, energy balance, and methane production in Korean Hanwoo heifers. Anim. Feed Sci. Technol. 234, $72-77$ (2017).

Ramirez-Restrepo, C. A., O'Neill, C. J., López-Villalobos, N., Padmanabha, J., \& McSweeney, C. Tropical cattle methane emissions: the role of natural statins supplementation. Anim. Prod. Sci. 54, 1294-1299 (2014).

Rangubhet, K. T. et al. Enteric methane emissions and protozoa populations in Holstein steers fed spent mushroom (Flammulina velutipes) substrate silage-based diets. Anim. Feed Sci. Technol. 234, 78-87 (2017).

Rapetti, L., Bava, L., Tamburini, A., Corvetto, G. M. Feeding behaviour, digestibility, energy balance and productive performance of lactating goats fed forage-based and forage-free diets. Ital. J. Anim. Sci. 4, 71-83 (2005).

Rapetti, L., Crovetto, G., Galassi, G., Anna, S., Giuseppe, S., Tamburini, A., \& Battelli, G. Effect of maize, rumen-protected fat and whey permeate on energy utilisation and milk fat composition in lactating goats. Ital. J. Anim. Sci. 1, 43-53 (2010).

Richmond, A. S., Wylie, A. R. G., Laidlaw, A. S., \& Lively, F. O. Methane emissions from beef cattle grazing on semi-natural upland and improved lowland grasslands. Animal 9, 130-137 (2015).

Rikhardsson, G., Johnson, K. A., \& Johnson, D. E. Effects of cimaterol on energetics and carcass characteristics of Suffolk ewe lambs. J. Anim. Sci. 69, 396-404 (1991).

Robertson, L. J., \& Waghorn, G. C. Dairy industry perspectives o methane emissions and production from cattle fed pasture or total mixed rations in New Zealand. Proc. NZ Grassl. Assoc. 62, 213-218 (2002).

Romero-Perez, A. et al. The potential of 3-nitrooxypropanol to lower enteric methane emissions from beef cattle. J. Anim. Sci. 92, 4682-4693 (2014).

Romero-Perez, A. et al. Sustained reduction in methane production from long-term addition of 3nitrooxypropanol to a beef cattle diet. J. Anim. Sci. 93, 1780-1791 (2015).

Rooke, J. A. et al. Hydrogen and methane emissions from beef cattle and their rumen microbial community vary with diet, time after feeding and genotype. Br. J. Nutr. 112, 398-407 (2014). 
Rossi, L. G. et al. Effect of ground soybean and starch on intake, digestibility, performance, and methane production of Nellore bulls. Anim. Feed Sci. Technol. 226, 39-47 (2017).

Rumpler, W. V., Johnson, D. E., \& Bates, D. B. The effect of high dietary cation concentration on methanogenesis by steers fed diets with and without ionophores. J. Anim. Sci. 62, 1737-1741 (1986).

Sahoo, B., Saraswat, M. L., Haque, N., \& Khan, M. Y. Energy balance and methane production in sheep fed chemically treated wheat straw. Small Rumin. Res. 35, 13-19 (1999).

Samal, L. et al. Impact of phytogenic feed additives on growth performance, nutrient digestion and methanogenesis in growing buffaloes. Anim. Prod. Sci. 58, 1056-1063 (2018).

Sano, H., Ito, T., \& Terashima, Y. Effect of Diet Forage-to-Concentrate Ratio on Partition of Dietary Energy and Nutrients in Fed and Fasted Sheep. J. Appl. Anim. Res. 25, 101-108 (2004).

Santoso,, B. et al. Effects of supplementing galacto-oligosaccharides, Yucca schidigera or nisin on rumen methanogenesis, nitrogen and energy metabolism in sheep. Livest. Prod. Sci. 91, 209-217 (2004).

Sato, Y. et al. Effects of supplementary desalted mother liquor as replacement of commercial salt in diet for Thai native cattle on digestibility, energy and nitrogen balance, and rumen conditions. Anim. Sci. J. 89, 10931101 (2018).

Savian, J. V. et al.. Rotatinuous stocking: A grazing management innovation that has high potential to mitigate methane emissions by sheep. J. Clean. Prod. 186, 602-608 (2018).

Schönhusen, U. et al. Effects of protozoa on methane production in rumen and hindgut of calves around time of weaning. Archiv. Anim. Nutr. 57, 279-295 (2003).

Sharma, V. K. et al. Buffalo heifers selected for lower residual feed intake have lower feed intake, better dietary nitrogen utilisation and reduced enteric methane production. J. Anim. Physio. Anim. Nutr. 102, 607614 (2018).

Shinkai, T. et al. Mitigation of methane production from cattle by feeding cashew nut shell liquid. J. Dairy Sci. 95, 5308-5316 (2012).

Shreck, A. L. et al. Effects of energy supplementation on energy losses and nitrogen balance of steers fed green-chopped wheat pasture I: calorimetry. J. Anim. Sci. 95, 2133-2143, (2017).

Silva, B. et al. Effect of sunflower oil supplementation on methane emissions of dairy cows grazing Urochloa brizantha cv. marandu. Anim. Prod. Sci. 57, 1431-1436 (2017).

Silva, F. A. S. et. al. Effect of different forage types and concentrate levels on energy conversion, enteric methane production, and animal performance of Holstein x Zebu heifers. Anim. Prod. Sci. 57, 2042-2050 (2016).

Śliwiński, B. J., Kreuzer, M., Wettstein, H. R., \& Machmüller, A. Rumen fermentation and nitrogen balance of lambs fed diets containing plant extracts rich in tannins and saponins, and associated emissions of nitrogen and methane. Archiv. Anim. Nutr. 56, 379-392 (2002).

Soltan, Y. A. et al. Contribution of condensed tannins and mimosine to the methane mitigation caused by feeding Leucaena leucocephala. Arch. Anim. Nutr. 67, 169-184 (2013).

Soltan, Y. A. et al. Progressive adaptation of sheep to a microencapsulated blend of essential oils: ruminal fermentation, methane emission, nutrient digestibility, and microbial protein synthesis. Anim. Feed Sci. Technol. 237, 8-18 (2018).

Stackhouse-Lawson, K. R. et al. Growth promoting technologies reduce greenhouse gas, alcohol, and ammonia emissions from feedlot cattle. J. Anim. Sci. 91, 5438-5447 (2013).

Staerfl, S. M., Zeitz, J. O., Kreuzer, M., \& Soliva, C. R. Methane conversion rate of bulls fattened on grass or maize silage as compared with the IPCC default values, and the long-term methane mitigation efficiency of adding acacia tannin, garlic, maca and lupine. Agric. Ecosyst. Environ. 148, 111-120 (2012).

Stoldt, A.-K. et al. Effects of rutin and buckwheat seeds on energy metabolism and methane production in dairy cows. J. Dairy Sci. 99, 2161-2168 (2016). 
Storlien, T. M. et al. Supplementation with crushed rapeseed causes reduction of methane emissions from lactating dairy cows on pasture. Anim. Prod. Sci. 57, 81-89 (2017).

Sun, X. Z. et al. Sheep fed forage chicory (Cichorium intybus) or perennial ryegrass (Lolium perenne) have similar methane emissions. Anim. Feed Sci. Technol. 172, 217-225 (2012).

Sutter, F. et al. Development of nitrogen and methane losses in the first eight weeks of lactation in Holstein cows subjected to deficiency of utilisable crude protein under restrictive feeding conditions. Archiv. Anim.

Nutr. 71, 1-20 (2017).

Sutton, J. D., Cammell, S. B., Beever, D. E., Humphries, D. J., \& Phipps, R. H. Energy and nitrogen balance of lactating dairy cows given mixtures of urea-treated whole-crop wheat and grass silage. Anim. Sci. 67, 203212 (1998).

Takahashi, J., Chaudhry, A. S., Beneke, R. G., \& Young, B. A. Modification of methane emission in sheep by cysteine and a microbial preparation. Sci. Total Environ. 204, 117-123 (1997).

Tangjitwattanachai, N., Phaowphaisal, I., Otsuka, M., \& Sommart, K. Enteric methane emission, energetic efficiency and energy requirements for the maintenance of beef cattle in the tropics. Jpn. Agric. Res. Q. 49, 399-407 (2015).

Tekippe, J. A. et al. Rumen fermentation and production effects of Origanum vulgare L. leaves in lactating dairy cows. J. Dairy Sci. 94, 5065-5079 (2011).

Terry, S. A. et al. Effect of humic substances on rumen fermentation, nutrient digestibility, methane emissions, and rumen microbiota in beef heifers. J. Anim. Sci. 96, 3863-3877 (2018).

Thornton, J. H., \& Owens, F. N. Monensin supplementation and methane production by steers. J. Anim. Sci. 52, 628-634 (1981).

Tiemann, T. T. et al. Effect of the tropical tannin-rich shrub legumes Calliandra calothyrsus and Flemingia macrophylla on methane emission and nitrogen and energy balance in growing lambs. Animal 2, 790-799 (2008).

Tiwari, C. M., Jadhao, S., Chandramoni, Murarilal, \& Khan, M. Y. Comparative Calorimetric Evaluation of Ammoniated Straw-Based Rations Supplemented with Low Levels of Untreated and Formaldehyde Treated Groundnut Cake and Fish Meal with Respect to Growing Buffalo Calves. Asian Australas. J. Anim. Sci. 13, 761-773 (2000).

Tomkins, N. W. et al. Manipulating rumen fermentation and methanogenesis using an essential oil and monensin in beef cattle fed a tropical grass hay. Anim. Feed Sci. Technol. 200, 25-34 (2015).

Tomkins, N. W., Colegate, S. M., \& Hunter, R. A. A bromochloromethane formulation reduces enteric methanogenesis in cattle fed grain-based diets. Anim. Prod. Sci. 49, 1053-1058 (2009).

Tomkins, N. W. et al. Nitrate supplementation has marginal effects on enteric methane production from Bos indicus steers fed Flinders grass (Iseilema spp.) hay, but elevates blood methaemoglobin concentrations. Anim. Prod. Sci. 58, 262-270 (2018).

Trigg, T. E. et al. The effect of level of feeding of pasture on its digestion by lactating dairy cows. Proc. NZ Soc. Anim. Prod. 40, 227-230 (1980).

Troy, S. M. et al. Effectiveness of nitrate addition and increased oil content as methane mitigation strategies for beef cattle fed two contrasting basal diets. J. Anim. Sci. 93, 1815-1823 (2015).

Tyrrell, H. F., Reynolds, P. J., \& Moe, P. W. Effect of diet on partial efficiency of acetate use for body tissue synthesis by mature cattle. J. Anim. Sci. 48, 598-606 (1979).

Tyrrell, H. F., Thomson, D. J., Waldo, D. R., Goering, H. K., \& Haaland, G. L. Utilization of energy and nitrogen by yearling Holstein cattle fed direct-cut alfalfa or orchardgrass ensiled with formic acid plus formaldehyde. J. Anim. Sci. 70, 3163-3177 (1992).

Van Gastelen, S. et al. Linseed oil and DGAT1 K232A polymorphism: effects on methane emission, energy and nitrogen metabolism, lactation performance, ruminal fermentation, and rumen microbial composition of Holstein-Friesian cows. J. Dairy Sci. 100, 8939-8957 (2017). 
Van Vugt, C. J. Impact of monensin on methane production and performance of cows fed forage diets. Proc. NZ Grassl. Assoc. 65, 362 (2005).

Van Wyngaard, J. D. V. et al. Effect of concentrate feeding level on methane emissions, production performance and rumen fermentation of Jersey cows grazing ryegrass pasture during spring. Anim. Feed Sci. Technol. 241, 121-132 (2018).

Van Wyngaard, J. D. V. et al. Effect of concentrate level on enteric methane emissions, production performance, and rumen fermentation of Jersey cows grazing kikuyu-dominant pasture during summer. $J$. Dairy Sci. 101, 9954-9966 (2018).

Van Wyngaard, J. D. V. et al. Effect of dietary nitrate on enteric methane emissions, production performance and rumen fermentation of dairy cows grazing kikuyu-dominant pasture during summer. Anim. Feed Sci. Technol. 244, 76-87 (2018).

Van Zijderveld, S. M. et al. Nitrate and sulfate: Effective alternative hydrogen sinks for mitigation of ruminal methane production in sheep. J. Dairy Sci. 93, 5856-5866 (2010).

Van Zijderveld, S. M. et al. Effects of a combination of feed additives on methane production, diet digestibility, and animal performance in lactating dairy cows. J. Dairy Sci. 94, 1445-1454 (2011).

Van Zijderveld, S. M. et al. Persistency of methane mitigation by dietary nitrate supplementation in dairy cows. J. Dairy Sci. 94, 4028-4038 (2011).

Van Zijderveld, S. M., Dijkstra, J., Perdok, H. B., Newbold, J. R., \& Gerrits, W. J. J. Dietary inclusion of diallyl disulfide, yucca powder, calcium fumarate, an extruded linseed product, or medium-chain fatty acids does not affect methane production in lactating dairy cows. J. Dairy Sci. 94, 3094-3104 (2011).

Veneman, J. B. et al. Does Dietary Mitigation of Enteric Methane Production Affect Rumen Function and Animal Productivity in Dairy Cows? PLoS One 10, e0140282 (2015).

Verma, V., Chaudhary, L. C., Agarwal, N., Bhar, R., \& Kamra, D. N. Effect of feeding mixture of garlic bulb and peppermint oil on methane emission, rumen fermentation and microbial profile in buffaloes. Anim. Nutr. Feed Techn. 12, 157-164 (2012).

Vermorel, M., \& Jouany, J. P. Effects of rumen protozoa on energy utilization by wethers of two diets based on ammonia-treated straw supplemented or not with maize. Asian-Australas. J. Anim. Sci. 2, 475-476 (1989). Von Keyserlingk, G. E. M., \& Mathison, G. W. The effect of ruminal escape protein and ambient temperature on the efficiency of utilization of metabolizable energy by lambs. J. Anim. Sci. 71, 2206-2217 (1993).

Vyas, D. et al. Effects of Propionibacterium strains on ruminal fermentation, nutrient digestibility and methane emissions in beef cattle fed a corn grain finishing diet. Animal 8, 1807-1815 (2014).

Vyas, D. et al. Optimal dose of 3-nitrooxypropanol for decreasing enteric methane emissions from beef cattle fed high-forage and high-grain diets. Anim. Prod. Sci. 58, 1049-1055 (2018).

Vyas, D. et al. The combined effects of supplementing monensin and 3-nitrooxypropanol on methane emissions, growth rate, and feed conversion efficiency in beef cattle fed high-forage and high-grain diets. $J$. Anim. Sci. 96, 2923-2938 (2018).

Vyas, D., McGeough, E. J., McGinn, S. M., McAllister, T. A., \& Beauchemin, K. A. Effect of spp. on ruminal fermentation, nutrient digestibility, and methane emissions in beef heifers fed a high-forage diet. $J$. Anim. Sci. 92, 2192-2201 (2014).

Waghorn, G. C., Tavendale, M. H., \& Woodfield, D. R. Methanogenesis from forages fed to sheep. Proc. NZ Grassl. Assoc. 64, 167-171(2002).

Wainman, F. W., \& Blaxter, K. L. The effect of grinding and pelleting on the nutritive value of poor quality roughages for sheep. J. Agric. Sci. 79, 435-445 (2009).

Wang, B. et al. Effects of isobutyrate supplementation on ruminal microflora, rumen enzyme activities and methane emissions in Simmental steers. J. Anim. Physiol. Anim. Nutr. 99, 123-131 (2015).

Wang, B. et al. Effects of eucalyptus oil and anise oil supplementation on rumen fermentation characteristics, methane emission, and digestibility in sheep. J. Anim. Sci. 96, 3460-3470 (2018). 
Wang, C. J., Wang, S. P., \& Zhou, H. Influences of flavomycin, ropadiar, and saponin on nutrient digestibility, rumen fermentation, and methane emission from sheep. Anim. Feed Sci. Technol. 148, $157-166$ (2009).

Wang, C., Wang, S., Zhou, H., \& Glindemann, T. Effects of forage composition and growing season on methane emission from sheep in the Inner Mongolia steppe of China. Ecol. Res. 22, 41-48 (2007).

Wang, L., \& Xue, B. Effects of Cellulase Supplementation on Nutrient Digestibility, Energy Utilization and Methane Emission by Boer Crossbred Goats. Asian-Australas. J. Anim. Sci. 29, 204-210 (2016).

Wang, R. et al. Nitrate improves ammonia incorporation into rumen microbial protein in lactating dairy cows fed a low-protein diet. J. Dairy Sci. 101, 9789-9799 (2018).

Wang, S. P. et al. Supplementation of pelleted hazel (Corylus avellana) leaves decreases methane and urinary nitrogen emissions by sheep at unchanged forage intake. Scientific Reports 8, 10 (2018).

Warner, D. et al. Effect of nitrogen fertilization rate and regrowth interval of grass herbage on methane emission of zero-grazing lactating dairy cows. J. Dairy Sci. 98, 3383-3393 (2015).

Warner, D. et al. Effects of nitrogen fertilisation rate and maturity of grass silage on methane emission by lactating dairy cows. Animal 10, 34-43 (2016).

Warner, D. et al. Effects of grass silage quality and level of feed intake on enteric methane production in lactating dairy cows. J. Anim. Sci. 95, 3687-3700 (2017).

Weisbjerg, M. R. et al. in Proceedings of the 9th Nordic Feed Science Conference (eds Udén, P et al.), 15-22 (Swedish University of Agricultural Sciences, Uppsala, 2018).

Whitelaw, F. G., Eadie, J. M., Bruce, L. A., \& Shand, W. J. Methane formation in faunated and ciliate-free cattle and its relationship with rumen volatile fatty acid proportions. Br. J. Nutr. 52, 261-275 (1984).

Williams, S. R. et al. Energy partitioning in herbage-fed dairy cows offered supplementary grain during an extended lactation. J. Dairy Sci. 96, 484-494 (2013).

Williams, S. R. O. et al. Influence of feeding supplements of almond hulls and ensiled citrus pulp on the milk production, milk composition, and methane emissions of dairy cows. J. Dairy Sci. 101, 2072-2083 (2018).

Wims, C. M. et al. Effect of pregrazing herbage mass on methane production, dry matter intake, and milk production of grazing dairy cows during the mid-season period. J. Dairy Sci. 93, 4976-4985 (2010).

Wischer, G. et al. Effects of long-term supplementation of chestnut and valonea extracts on methane release, digestibility and nitrogen excretion in sheep. Animal 8, 938-948 (2014).

Wood, T. A. et al. Encapsulated fumaric acid as a feed ingredient to decrease ruminal methane emissions. Anim. Feed Sci. Technol. 152, 62-71 (2009).

Woodward, S. L. Condensed tannins in birdsfoot trefoil (Lotus corniculatus) reduce methane emissions from dairy cows. Proc. NZ Grassl. Assoc. 64, 160-164 (2004).

Woodward, S. L. Supplementing dairy cows with oils to improve performance and reduce methane-does it work? Proc. NZ Grassl. Assoc. 66, 176 (2006).

Woodward, S. L., Waghorn, G. C., Lassey, K. R., \& Laboyrie, P. G. Does feeding sulla (Hedysarum coronarium) reduce methane emissions from dairy cows? Proc. NZ Grassl. Assoc. 62, 227-230 (2002).

Xue, B. et al. Milk production and energy efficiency of Holstein and Jersey-Holstein crossbred dairy cows offered diets containing grass silage. J. Dairy Sci. 94, 1455-1464 (2011).

Yan, T., Patterson, D. C., Gordon, F. J., \& Porter, M. G.. The effects of wilting of grass prior to ensiling on the response to bacterial inoculation. 1. Silage fermentation and nutrient utilization over three harvests. Anim. Sci. 62, 405-417 (2010).

Yáñez-Ruiz, D. R., Hart, K. J., Martin-Garcia, A. I., Ramos, S., \& Newbold, C. J. Diet composition at weaning affects the rumen microbial population and methane emissions by lambs. Anim. Prod. Sci. 48, 186188 (2008). 
Yang, C. J., Mao, S. Y., Long, L. M., \& Zhu, W. Y. Effect of disodium fumarate on microbial abundance, ruminal fermentation and methane emission in goats under different forage: concentrate ratios. Animal 6, 1788-1794 (2012).

Yang, K. et al. Effects of dietary supplementing tannic acid in the ration of beef cattle on rumen fermentation, methane emission, microbial flora and nutrient digestibility. J. Anim. Physio. Anim. Nutr. 101, 302-310 (2017).

Yaremcio, B. J., Engstrom, D. F., Mathison, G. W., Caine, W. R., \& Roth, L. A. Effect of ammoniation on the preservation and feeding value of barley grain for growing-finishing cattle. Can. J. Anim. Sci. 71, 439-455 (1991).

Yatoo, M. A. et al. Effect of feeding of blend of essential oils on methane production, growth, and nutrient utilization in growing buffaloes. Asian-Australas. J. Anim. Sci. 31, 672-676 (2018).

Yuan, Z. P. et al. Inhibition of methanogenesis by tea saponin and tea saponin plus disodium fumarate in sheep. J. Anim. Feed Sci. 16, 560-565 (2007).

Yulistiani, D., Puastuti, W., Haryanto, B., Purnomoadi, A., Kurihara, M., \& Thalib, A. Complete rumen modifier suplementation in corn cob silage basal diet of lamb reduces methane emission. Indonesian J. Agric. Sci. 18, 33-42 (2017).

Zhang, C. M. et al. Effects of supplementation of Simmental steers with 2-methylbutyrate on rumen microflora, enzyme activities and methane production. Anim. Feed Sci. Technol. 199, 84-92 (2015).

Zhang, C. M., Wang, J. K., Liu, J. X., \& Zhu, W. Y. in FAO/IAEA International Symposium on Sustainable Improvement of Animal Production and Health (eds Odonog, N. E., Garcia, M., and Viljoen, G. J.), 137-141 (FAO/IAEA, Vienna, 2010).

Zhang, H. et al. Energy and protein requirements for maintenance of Hu sheep during pregnancy. J. Integr. Agric. 17, 173-183 (2018).

Zhao, Y. G. et al. Effects of forage types on digestibility, methane emissions, and nitrogen utilization efficiency in two genotypes of hill ewes. J. Anim. Sci. 95, 3762-3771 (2017).

Zhou, Y. G. et al. Inhibition of rumen methanogenesis by tea saponins with reference to fermentation pattern and microbial communities in Hu sheep. Anim. Feed Sci. Technol. 166, 93-100 (2011). 
Supplementary Table 2. Mitigation strategies (categories and subcategories) included in this meta-analysis.

\begin{tabular}{|c|c|c|}
\hline Animal and feed management & Diet formulation & Rumen manipulation \\
\hline $\begin{array}{l}\text { Feed processing } \\
\text { Forage processing } \\
\text { Urea-treated straw } \\
\text { Grain processing } \\
\text { Genetic Selection } \\
\text { Low residual feed intake } \\
\text { Low CH4 emitter } \\
\text { Improving health } \\
\text { Improving pasture management } \\
\text { Grazing plus supplementation } \\
\quad \text { Grazing plus concentrate } \\
\text { Improved pasture } \\
\text { Increased Nitrongen fertilization } \\
\text { Legume-grass vs. grass only pastures } \\
\text { Reduced pre-grazing herbage mass } \\
\text { Increasing feeding level } \\
\text { Increasing forage quality } \\
\text { Decreasing grass maturity } \\
\text { Increasing corn silage maturity } \\
\text { Optimizing temperature } \\
\text { Total mixed ration feeding } \\
\text { Total mixed ration vs. grazing }\end{array}$ & $\begin{array}{l}\text { By-products } \\
\text { Fiber sources } \\
\text { Soybean hulls } \\
\text { Glycerol } \\
\text { Lipid sources } \\
\text { Extruded canola } \\
\text { Extruded linseed } \\
\text { Protein sources } \\
\quad \text { Distiller's dried grains with solubles } \\
\text { Soybean meal } \\
\text { Pulp sources } \\
\text { Citrus pulps } \\
\text { Decreasing forage-to-concentrate ratio } \\
\text { Barley } \\
\text { Corn } \\
\text { Minerals and Salts } \\
\text { Oils and fats } \\
\text { Canola oil } \\
\text { Coconut oil } \\
\text { Linseed oil } \\
\text { Oil blends } \\
\text { Rumen protected fat } \\
\text { Sunflower oil } \\
\text { Tallow } \\
\text { Oilseeds } \\
\text { Canola seed } \\
\text { Cottonseed } \\
\text { Linseed } \\
\text { Sunflower seed } \\
\text { Increasing protein } \\
\text { Tannifores forages } \\
\text { Lespedeza } \\
\text { Leucaena } \\
\text { Lotus } \\
\text { Sainfoin } \\
\text { Urea }\end{array}$ & 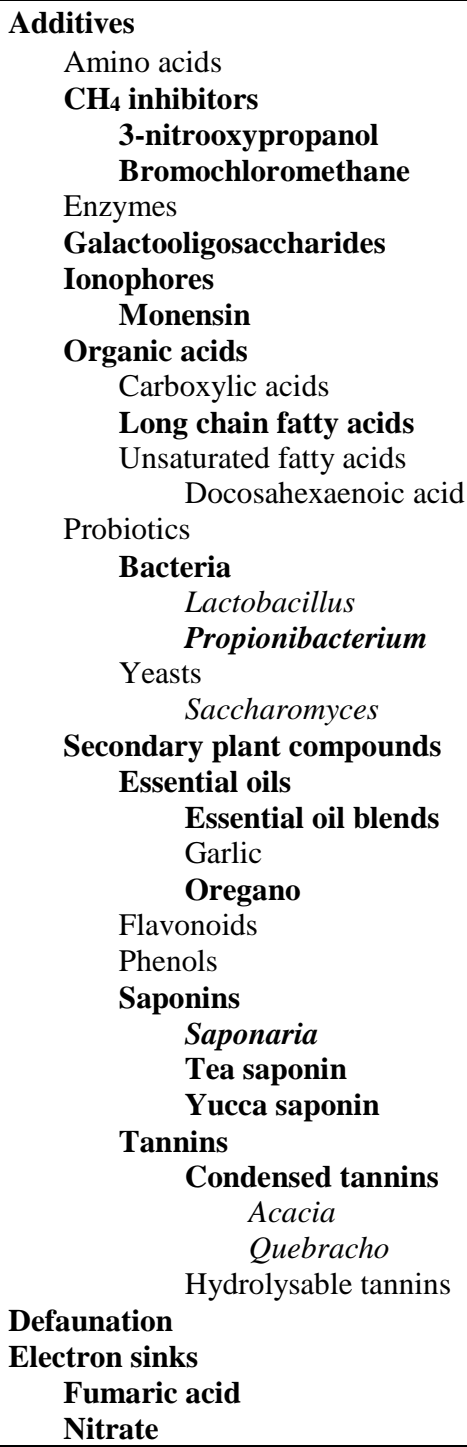 \\
\hline
\end{tabular}




\section{SUPPLEMENTARY FIGURES}

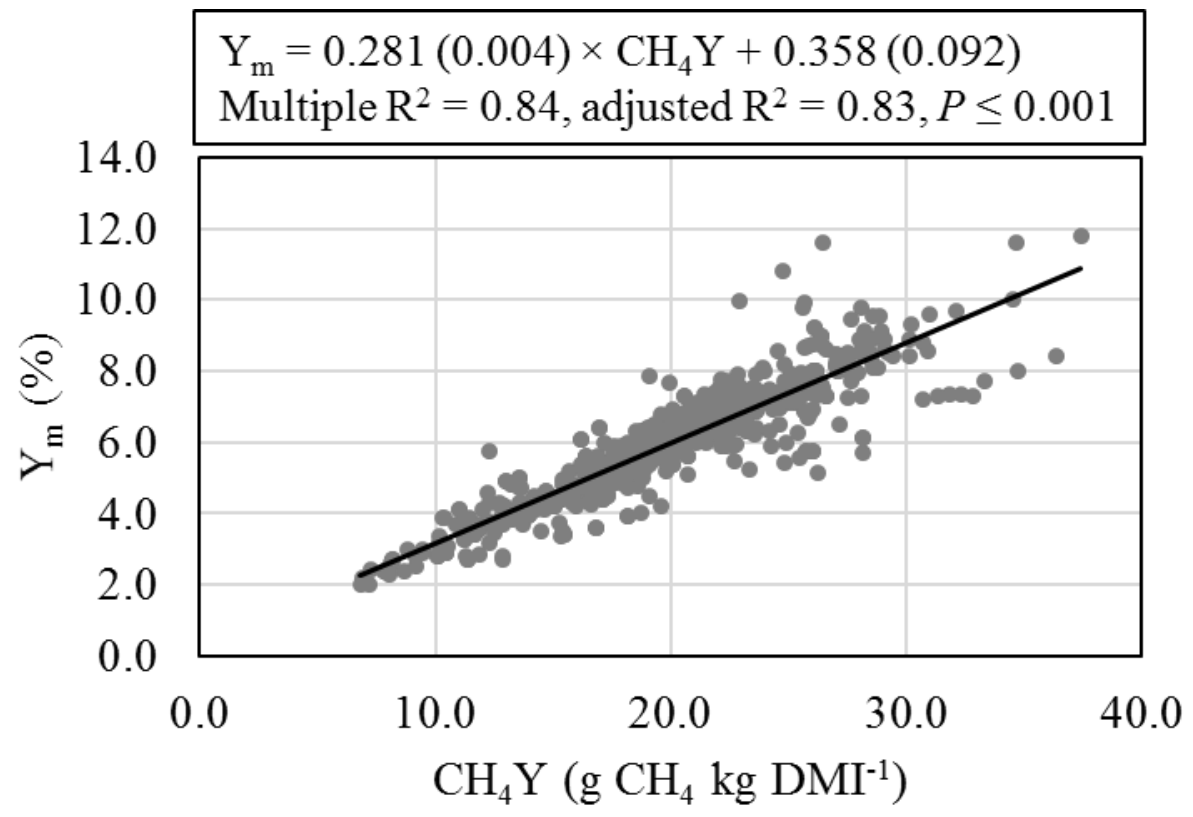

Supplementary Fig 1. Relationship between $\mathrm{CH}_{4} \mathrm{Y}\left(\mathrm{CH}_{4}\right.$ yield $=\mathrm{CH}_{4}$ per unit of feed dry matter intake, $\left.\mathrm{g} \mathrm{kg}^{-1}\right)$ and $\mathrm{Y}_{\mathrm{m}}\left(\mathrm{CH}_{4}\right.$ conversion factor $=$ $\mathrm{CH}_{4}$ energy $(\mathrm{MJ})$ per gross energy intake $\left.\left.(\mathrm{MJ}) \times 100, \%\right), \mathrm{MJ} \mathrm{CH}_{4} / \mathrm{MJ}\right]$ of treatment means included in the database of this study $(\mathrm{n}=783)$. Linear regression analysis was performed using the $\mathrm{lm}$ function in R. Standard errors are reported in parenthesis. 


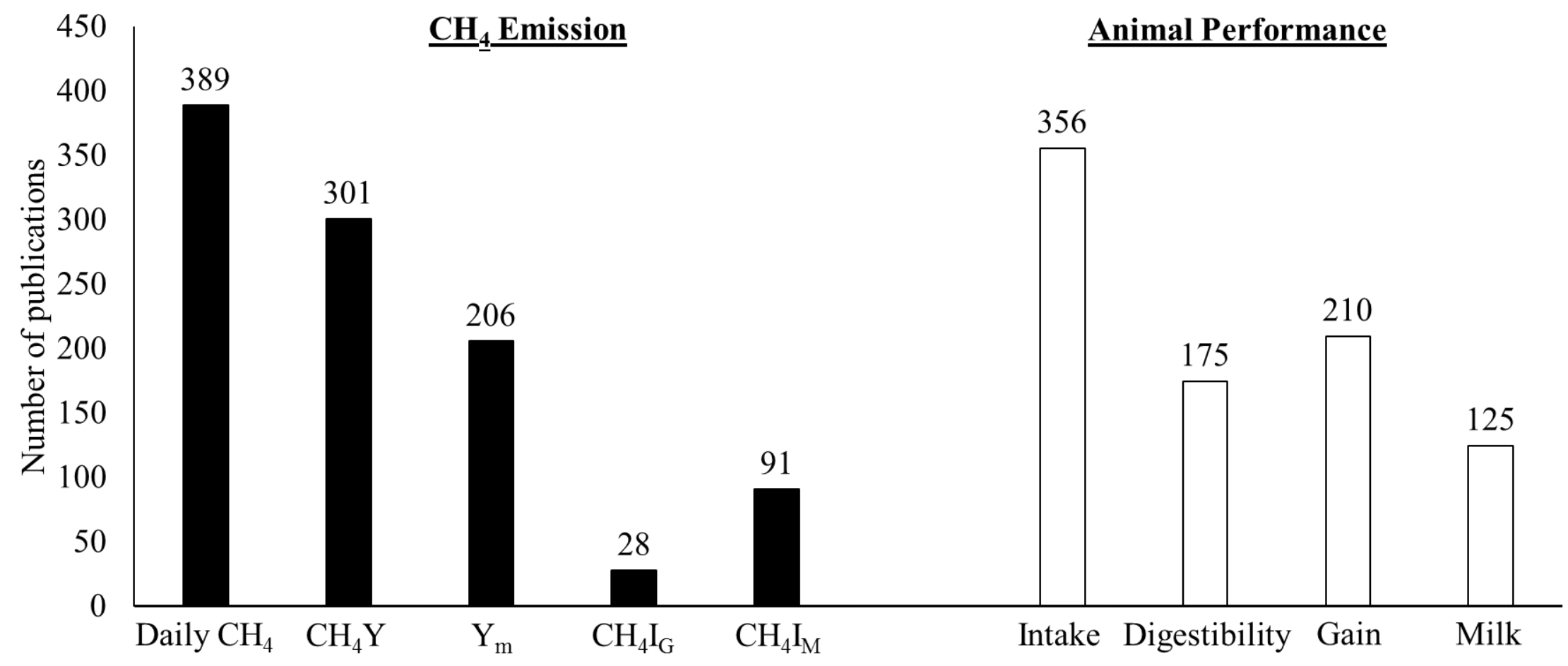

Supplementary Fig 2. Number of publications that reported methane $\left(\mathrm{CH}_{4}\right)$ emission and animal performance variables of the 425 studies that were analyzed in the current meta-analysis. Methane emission variables included in the analysis were: Daily $\mathrm{CH}_{4}=\mathrm{daily}_{\mathrm{CH}} \mathrm{emission}\left(\mathrm{g} \mathrm{d}^{-1}\right), \mathrm{CH}_{4} \mathrm{Y}=$ $\mathrm{CH}_{4}$ yield $\left(\mathrm{CH}_{4}\right.$ per unit of feed dry matter intake, $\left.\mathrm{g} \mathrm{kg}^{-1}\right), \mathrm{Y}_{\mathrm{m}}=\mathrm{CH}_{4}$ conversion factor $\left(\mathrm{CH}_{4}\right.$ energy $(\mathrm{MJ})$ per gross energy intake $\left.(\mathrm{MJ}) \times 100, \%\right)$, $\mathrm{CH}_{4} \mathrm{I}_{\mathrm{G}}=\mathrm{CH}_{4}$ intensity for weight gain $\left(\mathrm{CH}_{4}\right.$ per unit of weight gain of growing animals, $\left.\mathrm{g} \mathrm{kg}^{-1}\right), \mathrm{CH}_{4} \mathrm{I}_{\mathrm{M}}=\mathrm{CH}_{4}$ intensity for milk $\left(\mathrm{CH}_{4}\right.$ per unit of milk produced, $\left.\mathrm{g} \mathrm{kg}^{-1}\right)$, Intake $=$ feed intake $\left(\right.$ dry matter intake, $\left.\mathrm{kg} \mathrm{d}^{-1}\right)$, Digestibility = fiber digestibility (neutral detergent fiber digestibility, $\%$ ), Gain = weight gain (average daily gain, $\left.\mathrm{kg} \mathrm{d}^{-1}\right)$, and Milk = milk yield $\left(\mathrm{kg} \mathrm{d}^{-1}\right)$. 


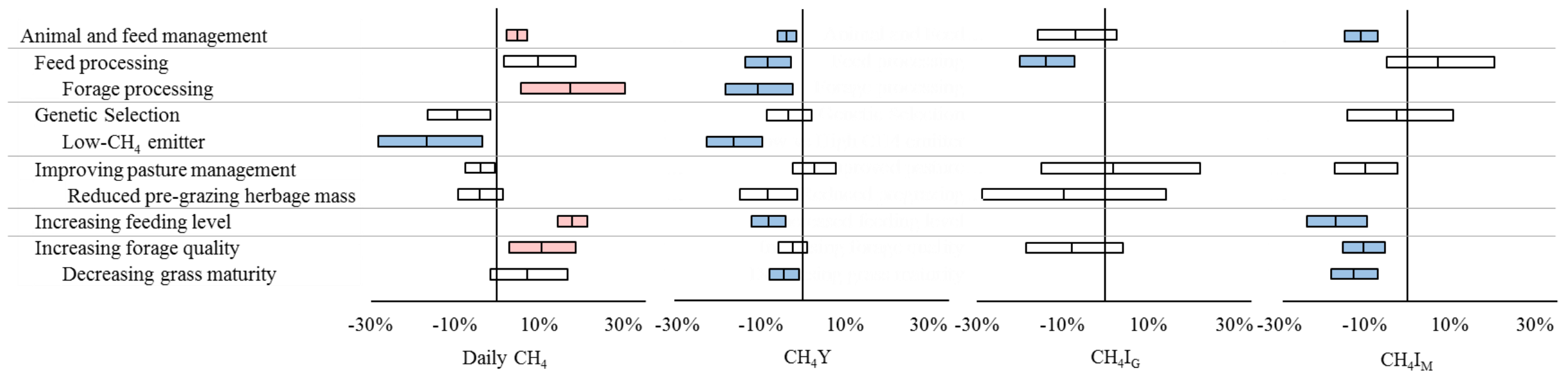

b

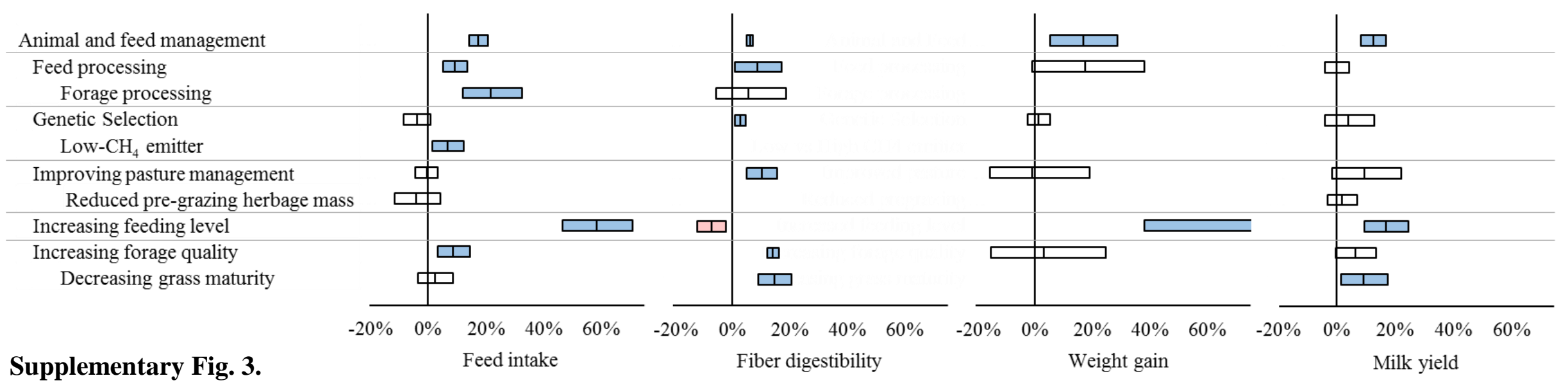

Relative treatment effects and 95\% confidence intervals of (a) Daily $\mathrm{CH}_{4}=$ daily $\mathrm{CH}_{4}$ emission $\left(\mathrm{g} \mathrm{d}^{-1}\right)$; $\mathrm{CH}_{4} \mathrm{Y}=\mathrm{CH}_{4}$ yield $\left(\mathrm{CH}_{4}\right.$ per unit of feed dry matter intake, $\left.\mathrm{g} \mathrm{kg}^{-1}\right) ; \mathrm{CH}_{4} \mathrm{I}_{\mathrm{G}}=\mathrm{CH}_{4}$ emission intensity for weight gain $\left(\mathrm{CH}_{4}\right.$ per unit of weight gain of growing animals, $\left.\mathrm{g} \mathrm{kg}^{-1}\right)$; and $\mathrm{CH}_{4} \mathrm{I}_{\mathrm{M}}=\mathrm{CH}_{4}$ emission intensity for milk $\left(\mathrm{CH}_{4}\right.$ per unit of milk produced, $\left.\mathrm{g} \mathrm{kg}^{-1}\right)$ and $(\mathbf{b})$ Feed intake (dry matter intake, kg d $\left.\mathrm{d}^{-1}\right)$; weight gain $($ average daily gain, $\mathrm{kg}$ $\left.\mathrm{d}^{-1}\right)$, milk yield $\left(\mathrm{kg} \mathrm{d}^{-1}\right)$; and fiber digestibility (neutral detergent fiber digestibility, \%) for animal and feed management strategies that had a significant effect (adjusted $P<0.05$ ) on daily $\mathrm{CH}_{4}, \mathrm{CH}_{4} \mathrm{Y}$, or $\mathrm{Y}_{\mathrm{m}}=$ methane conversion factor $\left[\mathrm{CH}_{4}\right.$ energy (MJ) per gross energy intake (MJ), \%]. Next higher mitigation categories were included for all significant categories (adjusted $P<0.05$ ) even if they were not significant (adjusted $P \geq 0.05$ ) 
Blue and red bars indicate significant desirable and undesirable effects (adjusted $P<0.05$ ), respectively, white bars indicate lack of significant effects (adjusted $P \geq 0.05$ ), and no bars indicate that no data were available. The relative treatment effect of increasing feeding level on weight gain is only partially shown; its relative treatment effect was $162 \%$ and its $95 \%$ CI was 38 to $398 \%$. 


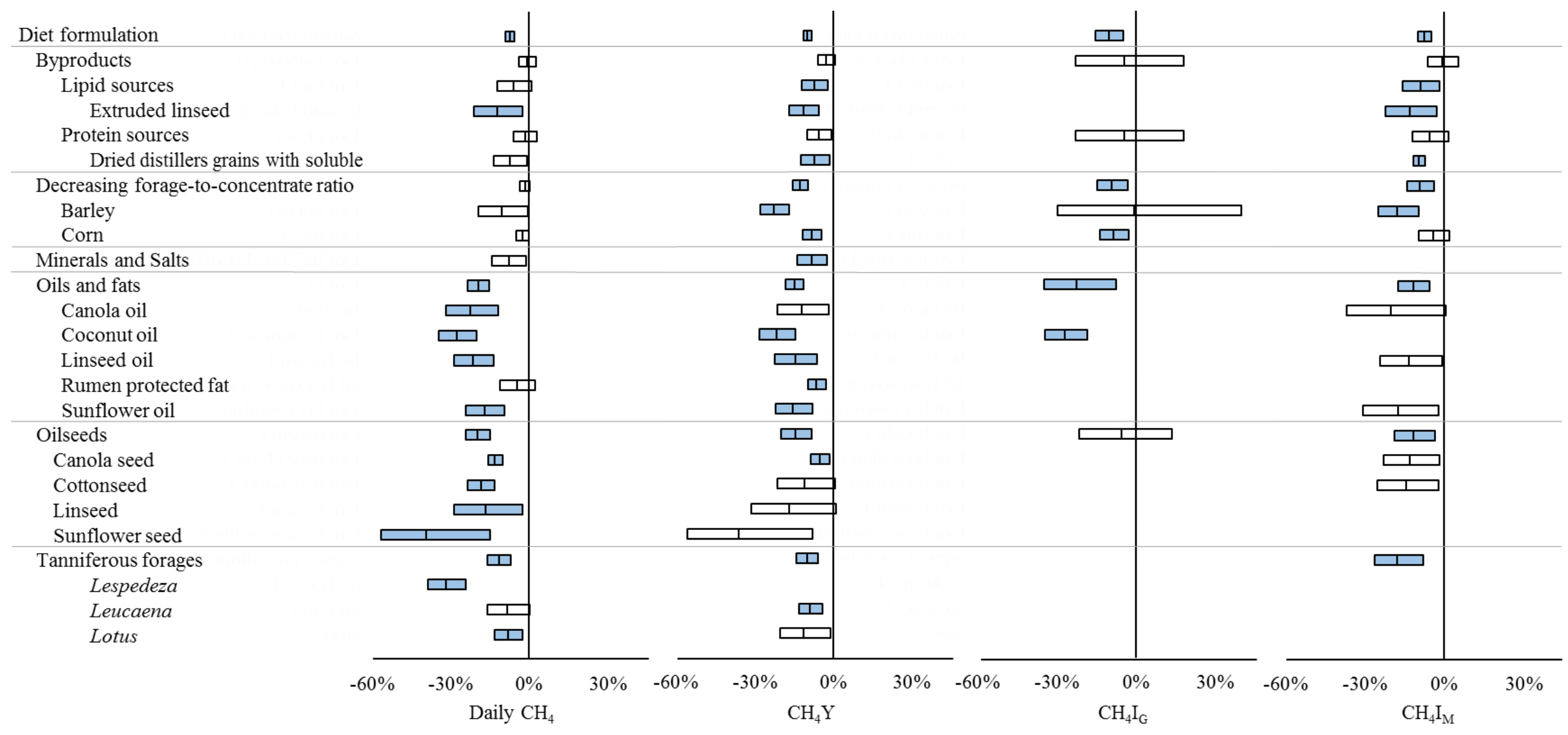




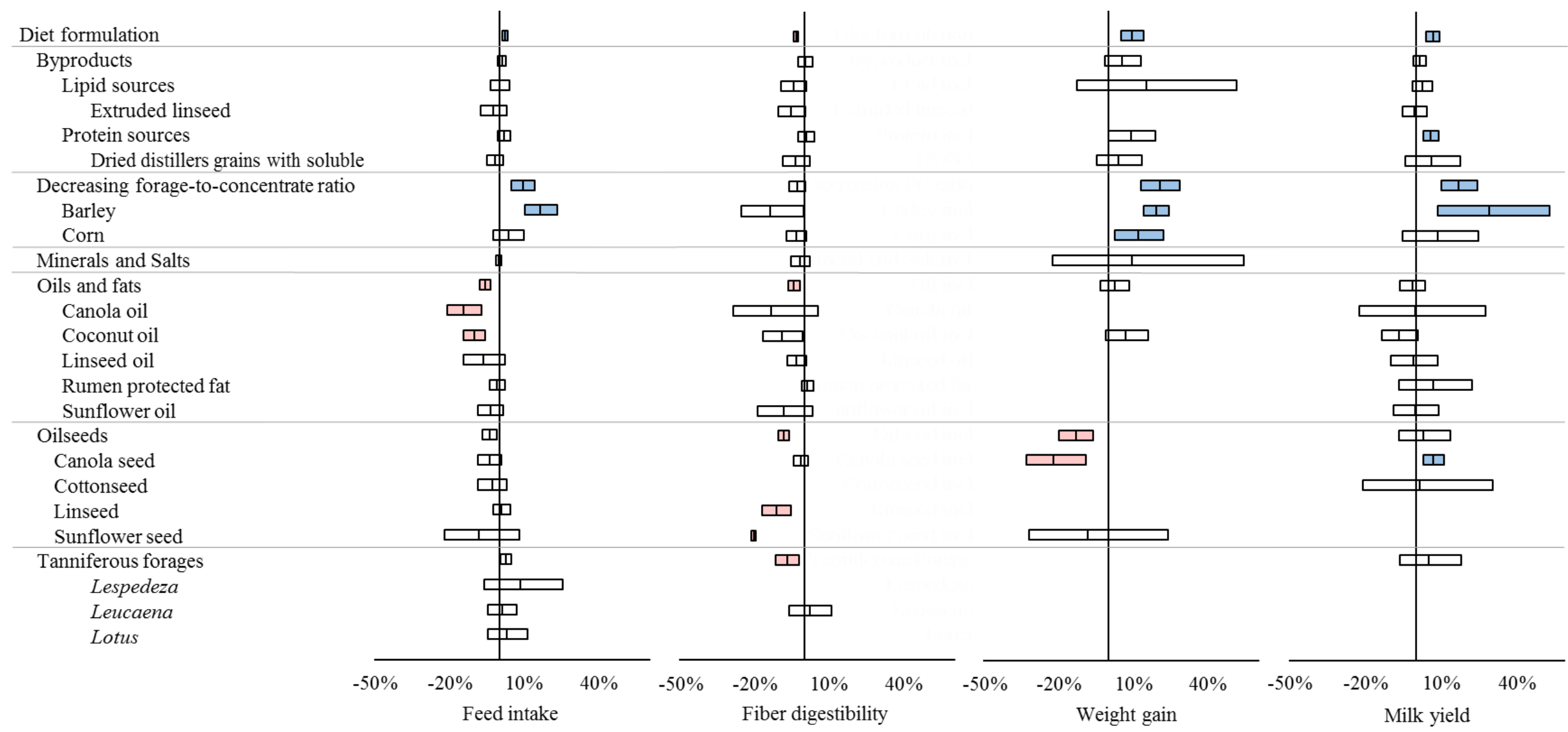

Supplementary Fig 4. Relative treatment effects and 95\% confidence intervals of (a) Daily $\mathrm{CH}_{4}=$ daily $\mathrm{CH}_{4} \mathrm{emission}\left(\mathrm{g} \mathrm{d}^{-1}\right)$; $\mathrm{CH}_{4} \mathrm{Y}=\mathrm{CH}_{4}$ yield $\left(\mathrm{CH}_{4}\right.$ per unit of feed dry matter intake, $\left.\mathrm{g} \mathrm{kg}^{-1}\right) ; \mathrm{CH}_{4} \mathrm{I}_{\mathrm{G}}=\mathrm{CH}_{4}$ emission intensity for weight gain $\left(\mathrm{CH}_{4}\right.$ per unit of weight gain of growing animals, $\mathrm{g}$ kg $\left.{ }^{1}\right)$; and $\mathrm{CH}_{4} \mathrm{I}_{\mathrm{M}}=\mathrm{CH}_{4}$ emission intensity for milk $\left(\mathrm{CH}_{4}\right.$ per unit of milk produced, $\left.\mathrm{g} \mathrm{kg}^{-1}\right)$ and $(\mathbf{b})$ Feed intake $=$ feed intake $\left(\mathrm{dry}\right.$ matter intake, $\left.\mathrm{kg} \mathrm{d} \mathrm{d}^{-1}\right)$; weight gain (average daily gain, $\left.\mathrm{kg} \mathrm{d}^{-1}\right)$, milk yield $\left(\mathrm{kg} \mathrm{d}^{-1}\right)$; and fiber digestibility (neutral detergent fiber digestibility, \%) for diet formulation strategies that had a significant effect (adjusted $P<0.05$ ) on daily $\mathrm{CH}_{4}, \mathrm{CH}_{4} \mathrm{Y}$, or $\mathrm{Y}_{\mathrm{m}}=$ methane conversion factor $[\mathrm{CH} 4 \mathrm{energy}(\mathrm{MJ})$ per gross energy intake (MJ), \%]. Next higher mitigation categories were included for all significant categories (adjusted $P<0.05$ ) even if they were not significant (adjusted $P \geq 0.05$ ). Blue and red bars indicate significant desirable and undesirable effects (adjusted $P<0.05$ ), respectively, white bars indicate lack of significant effects (adjusted $P \geq 0.05$ ), and no bars indicate that no data were available. Weight gain for tanniferous forage was not significant (not shown, because it was analyzed with standardized relative difference instead of log ratio of means that was used for the remaining analyses). 
a

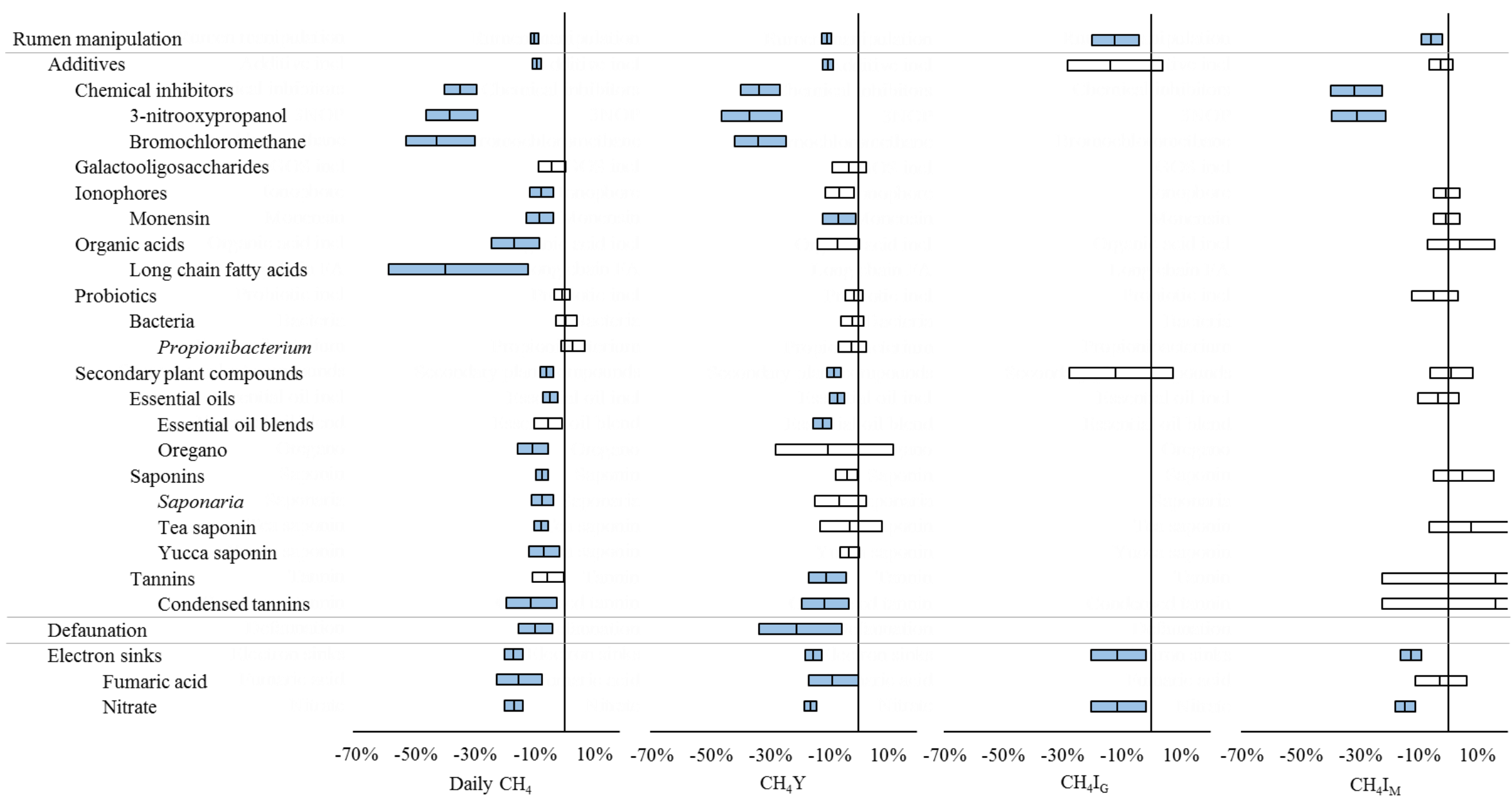




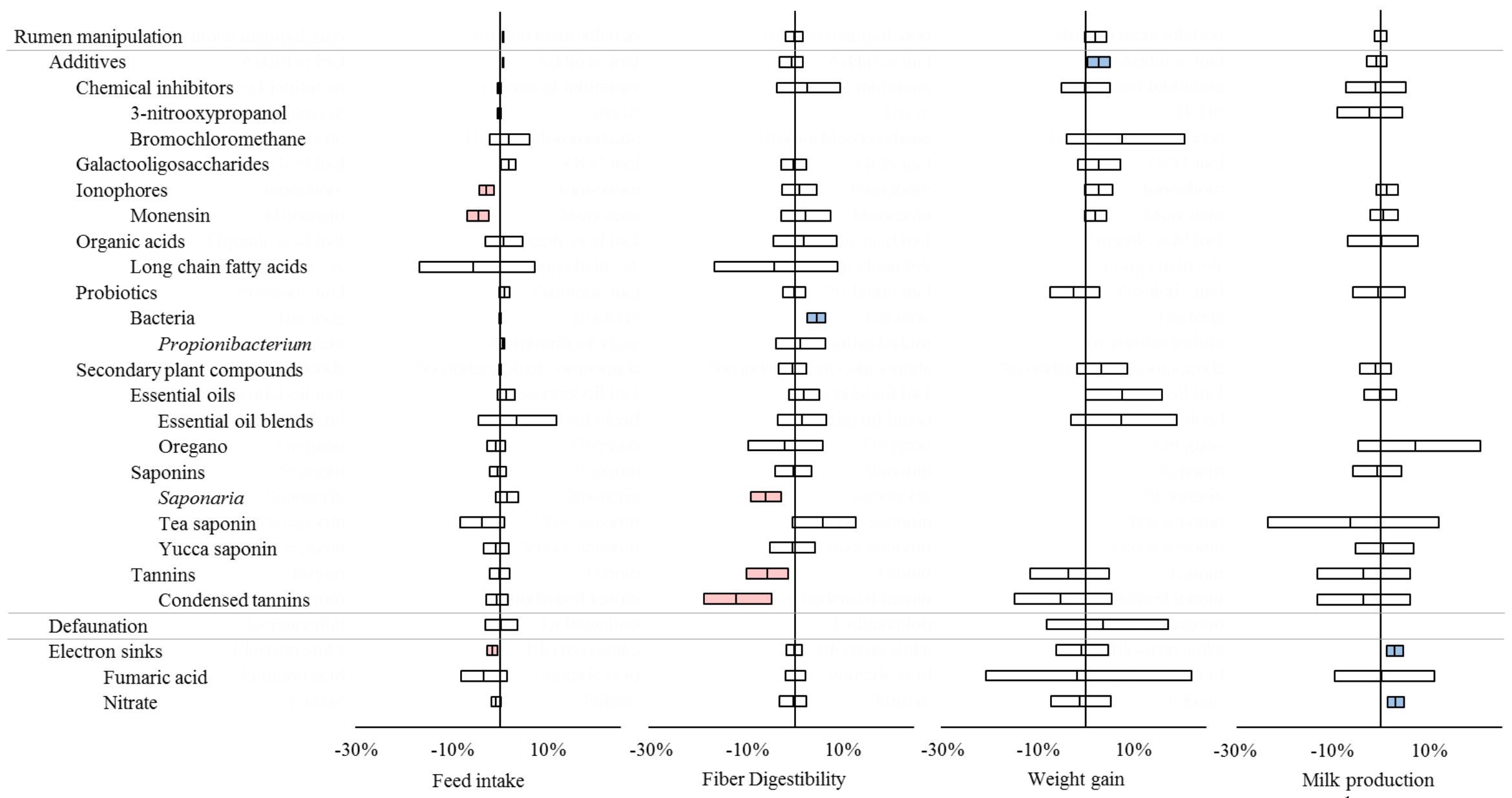

Supplementary Fig 5. Relative treatment effects and 95\% confidence intervals of (a) Daily $\mathrm{CH}_{4}=$ daily $\mathrm{CH}_{4} \mathrm{emission}\left(\mathrm{g} \mathrm{d}^{-1}\right)$; $\mathrm{CH}_{4} \mathrm{Y}$ $=\mathrm{CH}_{4}$ yield $\left(\mathrm{CH}_{4}\right.$ per unit of feed dry matter intake, $\left.\mathrm{g} \mathrm{kg}^{-1}\right) ; \mathrm{CH}_{4} \mathrm{I}_{\mathrm{G}}=\mathrm{CH}_{4}$ emission intensity for weight gain $\left(\mathrm{CH}_{4}\right.$ per unit of weight gain of growing animals, $\left.\mathrm{g} \mathrm{kg}^{-1}\right)$; and $\mathrm{CH}_{4} \mathrm{I}_{\mathrm{M}}=\mathrm{CH}_{4}$ emission intensity for milk $\left(\mathrm{CH}_{4}\right.$ per unit of milk produced, $\left.\mathrm{g} \mathrm{kg}^{-1}\right)$ and $(\mathbf{b})$ Feed intake $=$ feed intake $\left(\right.$ dry matter intake, $\left.\mathrm{kg} \mathrm{d}^{-1}\right)$; Weight gain (average daily gain, $\mathrm{kg} \mathrm{d}^{-1}$ ), Milk production $\left(\mathrm{kg} \mathrm{d}^{-1}\right)$; and Fiber 
digestibility (neutral detergent fiber digestibility, $\%$ ) for rumen manipulation strategies that had a significant effect (adjusted $P<0.05$ ) on daily $\mathrm{CH}_{4}, \mathrm{CH}_{4} \mathrm{Y}$, or $\mathrm{Y}_{\mathrm{m}}=$ methane conversion factor $\left[\mathrm{CH}_{4}\right.$ energy $(\mathrm{MJ})$ per gross energy intake (MJ), \%]. Next higher mitigation categories were included for all significant categories (adjusted $P<0.05$ ) even if they were not significant (adjusted $P \geq 0.05$ ), and no bars indicate that no data were available. Blue and red bars indicate significant desirable and undesirable effects (adjusted $P<0.05$ ), respectively, white bars indicate lack of significant effects (adjusted $P \geq 0.05$ ), and no bars indicate that no data were available.

Weight gain for tanniferous forage was not significant (not shown, because it was analyzed with standardized relative difference instead of log ratio of means that was used for the remaining analyses). The relative treatment effect of tannin and condensed tannin on $\mathrm{CH}_{4} \mathrm{I}_{\mathrm{M}}$ is only partially shown; its relative treatment effect was for both $-3.5 \%$ and its $95 \%$ CI was -15.1 to $9.5 \%$. 